\title{
Advances in Enhanced Oil Recovery Processes
}

\author{
Laura Romero-Zerón \\ University of New Brunswick, Chemical Engineering Department
}

Canada

\section{Introduction}

In the last few years, Enhanced Oil Recovery (EOR) processes have re-gained interest from the research and development phases to the oilfield EOR implementation. This renewed interest has been furthered by the current high oil price environment, the increasing worldwide oil demand, the maturation of oilfields worldwide, and few new-well discoveries (Aladasani \& Bai, 2010).

Oil recovery mechanisms and processes are concisely reviewed in this chapter. A brief introduction to primary and secondary oil recovery stages is provided; while the main focus of the chapter is given to EOR processes with emphasis on EOR emerging technological trends.

\section{Hydrocarbon recovery}

Hydrocarbon recovery occurs through two main processes: primary recovery and supplementary recovery. Primary recovery refers to the volume of hydrocarbon produced by the natural energy prevailing in the reservoir and/or artificial lift through a single wellbore; while supplementary or secondary hydrocarbon recovery refers to the volume of hydrocarbon produced as a result of the addition of energy into the reservoir, such as fluid injection, to complement or increase the original energy within the reservoir (Dake, 1978; Lyons \& Plisga, 2005).

\subsection{Primary oil recovery mechanisms}

The natural driving mechanisms of primary recovery are outlined as follows.

- $\quad$ Rock and liquid expansion drive

- Depletion drive

- Gas cap drive

- Water drive

- Gravity drainage drive

- Combination drive

Hydrocarbon reservoirs are unique; each reservoir presents its own geometric form, geological rock properties, fluid characteristics, and primary driving mechanism. Yet, similar reservoirs are categorized based on their natural recovery mechanism. Table 1 
summarizes the performance of each of the primary recovery mechanisms in terms of pressure decline rate, gas-oil ratio, water production, well behaviour, and oil recovery as presented by Ahmed \& McKinney (2005).

Primary recovery from oil reservoirs is influenced by reservoir rock properties, fluid properties, and geological heterogeneities; so that on a worldwide basis, the most common primary oil recovery factors range from $20 \%$ and $40 \%$, with an average around $34 \%$,while the remainder of hydrocabon is left behind in the reservoir (Satter et al., 2008).

Once the natural reservoir energy has been depleted and the well oil production rates decline during primary recovery, it is necessary to provide additional energy to the resevoirfluid system to boost or maintain the production level through the application of secondary production methods based on fluid injection (Satter et al., 2008).

\subsection{Supplementary or secondary hydrocarbon recovery}

Secondary hydrocarbon (oil and/or gas) involves the introduction of artificial energy into the reservoir via one wellbore and production of oil and/or gas from another wellbore. Usually secondary recovery include the immiscible processes of waterflooding and gas injection or gas-water combination floods, known as water alternating gas injection (WAG), where slugs of water and gas are injected sequentially. Simultaneous injection of water and gas (SWAG) is also practiced, however the most common fluid injected is water because of its availability, low cost, and high specific gravity which facilitates injection (Dake, 1978; Lyons \& Plisga, 2005; Satter et al., 2008 ).

The optimization of primary oil recovery is generally approached through the implementation of secondary recovery processes at early stages of the primary production phase before reservoir energy has been depleted. This production strategy of combining primary and secondary oil recovery processes commonly renders higher oil recovery if compared to the oil production that would be obtained through the single action of the natural driving mechanisms during primary oil recovery (Lyons \& Plisga, 2005).

\subsubsection{Waterflood process}

Waterflooding is implemented by injecting water into a set of wells while producing from the surrounding wells. Waterflooding projects are generally implemented to accomplish any of the following objectives or a combination of them:

- $\quad$ Reservoir pressure maintenance

- Dispose of brine water and/or produced formation water

- As a water drive to displace oil from the injector wells to the producer wells

Over the years, waterflooding has been the most widely used secondary recovery method worldwide. Some of the reasons for the general acceptance of waterflooding are as follows (Satter et al. 2008). Water is an efficient agent for displacing oil of light to medium gravity, water is relatively easy to inject into oil-bearing formations, water is generally available and inexpensive, and waterflooding involves relatively lower capital investment and operating costs that leads to favourable economics. 


\begin{tabular}{|c|c|c|}
\hline $\begin{array}{c}\text { Primary Recovery } \\
\text { Mechanism }\end{array}$ & \multicolumn{2}{|r|}{ Characteristics } \\
\hline \multirow{5}{*}{$\begin{array}{l}\text { (1) } \\
\text { Rock and liquid } \\
\text { expansion drive }\end{array}$} & $\begin{array}{l}\text { Reservoir } \\
\text { pressure }\end{array}$ & $\begin{array}{l}\text { Above bubble point: rapid and continuous pressure decline until bubble point } \\
\text { is reached. }\end{array}$ \\
\hline & $\begin{array}{l}\text { Gas-oil ratio } \\
\text { (GOR) }\end{array}$ & Above bubble point: GOR remains low and constant. \\
\hline & $\begin{array}{c}\text { Water } \\
\text { production }\end{array}$ & Little or no water production \\
\hline & $\begin{array}{c}\text { Well } \\
\text { behavior }\end{array}$ & Requires pumping at early stage \\
\hline & Oil recovery & $\begin{array}{l}\text { Least efficient driving mechanism. Oil recovery efficiency typically varies } \\
\text { from } 1 \% \text { to } 5 \% \text {, with an average of } 3 \% \text {. }\end{array}$ \\
\hline & $\begin{array}{l}\text { Reservoir } \\
\text { pressure }\end{array}$ & Declines rapidly and continuously \\
\hline (2) & $\begin{array}{l}\text { Gas-oil ratio } \\
\text { (GOR) }\end{array}$ & Increases to a maximum and then declines \\
\hline $\begin{array}{l}\text { Solution gas drive } \\
\text { Dissolved gas drive }\end{array}$ & $\begin{array}{c}\text { Water } \\
\text { production }\end{array}$ & Little or no water production \\
\hline Internal gas drive & $\begin{array}{c}\text { Well } \\
\text { behavior }\end{array}$ & Requires pumping at early stage \\
\hline & Oil recovery & $\begin{array}{c}\text { Very inefficient driving mechanism. } \\
\text { Varies from less than } 5 \% \text { to about } 30 \% \text {, with an average of } 16 \% .\end{array}$ \\
\hline & $\begin{array}{l}\text { Reservoir } \\
\text { pressure }\end{array}$ & Declines slowly and continuously \\
\hline & $\begin{array}{l}\text { Gas-oil ratio } \\
\text { (GOR) }\end{array}$ & $\begin{array}{l}\text { Increases continuously and as the expanding gas cap reaches the producing } \\
\text { intervals, the gas-oil ratio increases sharply and finally drops. }\end{array}$ \\
\hline Gas cap drive & $\begin{array}{c}\text { Water } \\
\text { production }\end{array}$ & Absent or negligible \\
\hline & $\begin{array}{c}\text { Well } \\
\text { behavior }\end{array}$ & Tends to flow longer than depletion drive reservoirs \\
\hline & Oil recovery & Ranges from $20 \%$ to $40 \%$, with an average of $25 \%$ \\
\hline & $\begin{array}{l}\text { Reservoir } \\
\text { pressure }\end{array}$ & Remains high \\
\hline$\stackrel{(4)}{\text { Water drive }}$ & $\begin{array}{l}\text { Gas-oil ratio } \\
\text { (GOR) }\end{array}$ & Remains low \\
\hline $\begin{array}{l}\text { Usually the most } \\
\text { efficient reservoir }\end{array}$ & $\begin{array}{c}\text { Water } \\
\text { production }\end{array}$ & Stars early and increases to appreciable amounts \\
\hline driving force & $\begin{array}{c}\text { Well } \\
\text { behavior }\end{array}$ & Flows until water production gets excessive \\
\hline & Oil recovery & Ranges from $30 \%$ to $80 \%$ \\
\hline & $\begin{array}{l}\text { Reservoir } \\
\text { pressure }\end{array}$ & Rapid pressure decline \\
\hline & $\begin{array}{l}\text { Gas-oil ratio } \\
\text { (GOR) }\end{array}$ & Commonly low gas-oil ratios \\
\hline Gravity drainage drive & $\begin{array}{c}\text { Water } \\
\text { production }\end{array}$ & Little or no water production \\
\hline & $\begin{array}{c}\text { Well } \\
\text { behavior }\end{array}$ & $\begin{array}{c}\text { Structurally low wells show low GOR } \\
\text { Structurally high wells show increasing GOR }\end{array}$ \\
\hline & Oil recovery & $\begin{array}{l}\text { Varies broadly but usually high oil recoveries are observed. Recoveries up to } \\
\qquad 80 \% \text { have been reported. }\end{array}$ \\
\hline & $\begin{array}{l}\text { Reservoir } \\
\text { pressure }\end{array}$ & Relatively rapid pressure decline \\
\hline & $\begin{array}{l}\text { Gas-oil ratio } \\
\text { (GOR) }\end{array}$ & Manage to maintain low GOR \\
\hline Combination drive & $\begin{array}{c}\text { Water } \\
\text { production }\end{array}$ & Slow increase of water production \\
\hline (2) $+(4)$ & $\begin{array}{c}\text { Well } \\
\text { behavior }\end{array}$ & $\begin{array}{c}\text { Structurally low wells show low GORs } \\
\text { Structurally high wells show increasing GORs }\end{array}$ \\
\hline & Oil recovery & $\begin{array}{l}\text { Usually higher than depletion drive reservoirs but less than recovery from } \\
\text { water drive or gas cap drive reservoirs. Ultimate recovery depends on the } \\
\text { degree to which it is possible to reduce the magnitude of recovery by } \\
\text { depletion drive. }\end{array}$ \\
\hline
\end{tabular}

Table 1. Primary Recovery Mechanisms Performance (Adapted from Ahmed \& McKinney, 2005; Satter et al. 2008). 
Waterflooding is generally implemented by following various types of well flooding arrangements such as pattern flooding, peripheral flooding, and crestal flooding, among others. Pattern flooding is used in reservoirs having a small dip (not flat-lying reservoirs) and a large surface area. Figure 1 presents the geometry of common pattern floods. Economic factors are the main criteria for the selection of a specific pattern geometry; these factors include the cost of drilling new wells, the cost of switching existing wells to a different type (i.e., a producer to an injector), and the loss of revenue from the production when making a switch from a producer to an injector. For instance, the direct-line-drive and staggered-line-drive patterns are frequently used because they require the lowest investment. However, if the reservoir characteristics yield lower injection rates than those desired, the operator should consider using either a seven- or a nine-spot pattern where there are more injection wells per pattern than producing wells as suggested by Craft \& Hawkins, (1991).

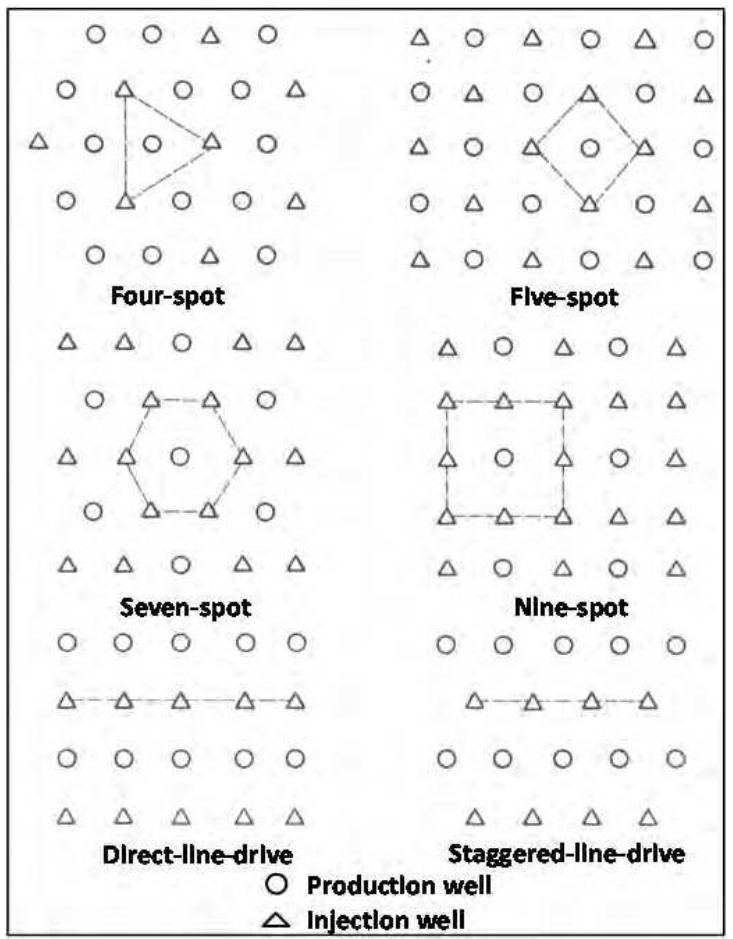

Fig. 1. Geometry of common regular pattern floods (Craft \& Hawkins, 1991)

In the regular patterns shown in Fig. 1, the producer wells are always located in the centre of the pattern, surrounded by the injector wells; while the opposite is true for the inverted pattern floods, where the injectors are drilled in the middle of the pattern, and producers are at the corners.

Optimization of oil recovery during the life of a waterflood project is approached by changing over time the injector/producer pattern and well spacing. Thus, based on simulation studies and economic analyses, producers are converted to injectors, infill wells are drilled, and a relatively dense well spacing is implemented at certain stages of recovery. 
However, the implementation of any pattern flood modification is conditioned to the expected increase in oil recovery and whether the incremental oil justifies the capital expenditure and operating costs. Figure 2 shows an example in which a waterflood operation was initiated using an inverted 9-spot pattern that was gradually transformed to a regular 5-spot pattern at later stages of waterflooding through well conversion and infill drilling (Satter et al., 2008).

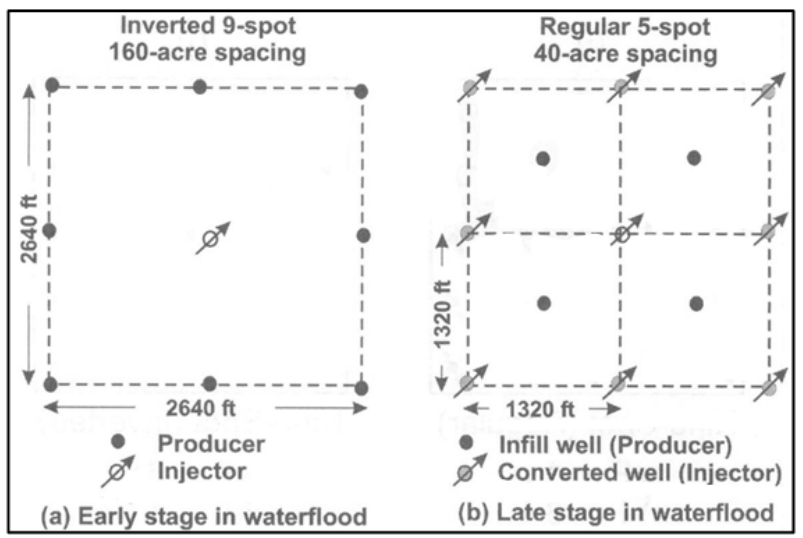

Fig. 2. Modifications of the injector/producer pattern and well spacing over the life of a waterflooding project to optimize the recovery of oil: (a) Early stage and (b) Late stage (Satter et al., 2008).

In peripheral flooding, the injection wells are positioned around the periphery of a reservoir. In Figure 3, two cases of peripheral floods involving reservoirs with underlying aquifers are shown. In the anticlinal reservoir of Fig. 3a, the injector wells are placed in such a manner that the injected water either enters the aquifer or is near the aquifer-reservoir interface displacing oil towards the producer wells located at the upper part of the reservoir, thus in this case the geometrical well configuration is similar to a ring of injectors surrounding the producers. For the monoclinal (dipping or not flat lying) reservoir illustrated in Fig. 3b, the injector wells are placed down dip to take advantage of gravity segregation, thus the injected water either enters the aquifer or enters near the aquifer-reservoir interface. In this situation, the well configuration renders the grouping of all the injector wells on the structurally lower side of the reservoir (Craft \& Hawkins, 1991).

In reservoirs having sharp structural features, the water injection wells can be located at the crest of the structure to efficiently displace oil located at the top of the reservoir; this is known as crestal injection. In any case, injection well configuration and well spacing depend on several factors that include rock and fluid characteristics, reservoir heterogeneities, optimum injection pressure, time frame for recovery, and economics (Satter et al., 2008).

Under favorable fluid and rock properties, current technology, and economics, waterflooding oil recovery ranges from $10 \%$ to $30 \%$ of the original oil in place (OOIP).

\subsubsection{Low-salinity waterflooding}

Low-salinity waterflooding is an emerging process that has demonstrated to increase oil recovery. The mechanisms associated to this processes are still unclear, however the favorable oil 
recovery are attributed to fine migration or permeability reduction and wettability alteration in sandstones when the salinity or total solids dissolved (TSD) in the injected water is reduced. In the case of carbonate formations, the active mechanisms are credited to wettability alteration and to interfacial tension reductions between the low salinity injected water and the oil in the carbonate formation (Okasha \& Al-Shiwaisk, 2009; Sheng 2011).This waterflooding process requires more research in order to clearly establish the mechanisms involved and an understanding of the application boundaries based on the type of reservoir formation to avoid adverse effects on reservoir permeability caused by the injection of water that could negatively interact with the formation water and the formation rock (Aladasani \& Bai, 2010).

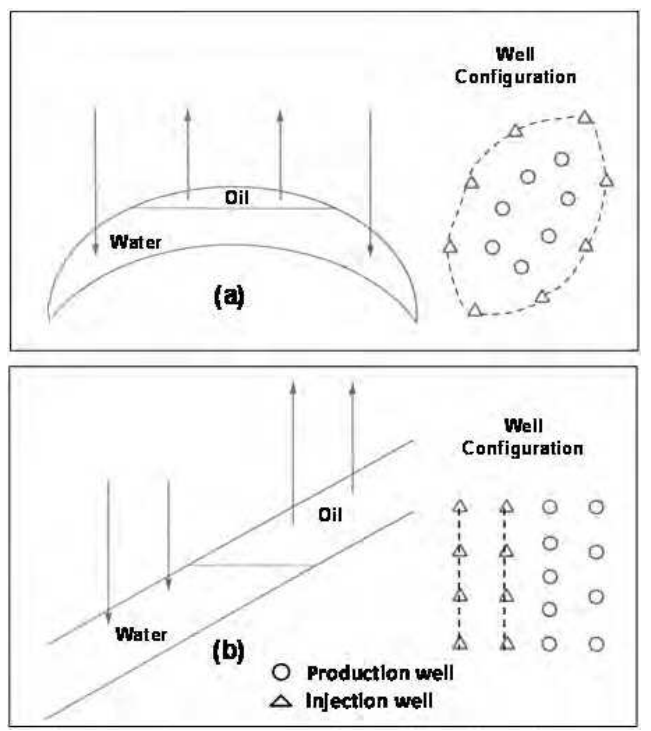

Fig. 3. Well Configuration for peripherial waterflooding of reservoirs with underlying aquifers: (a) Anticlinal reservoir and (b) Monoclinal reservoir (Craft \& Hawkins, 1991).

\subsubsection{Gas injection}

Immiscible gas (one that will not mix with oil) is injected to maintain formation pressure, to slow the rate of decline of natural reservoir drives, and sometimes to enhance gravity drainage. Immiscible gas is commonly injected in alternating steps with water to improve recovery. Immiscible gases include natural gas produced with the oil, nitrogen, or flue gas. Immiscible gas injected into the well behaves in a manner similar to that in a gas-cap drive: the gas expands to force additional quantities of oil to the surface. Gas injection requires the use of compressors to raise the pressure of the gas so that it will enter the formation pores (Van Dyke, 1997).

Immiscible gas injection projects on average render lower oil recovery if compared to waterflooding projects, however in some situations the only practicable secondary recovery process is immiscible gas injection. Those situations include very low permeability oil formations (i.e. shales), reservoir rock containing swelling clays, and thin formations in which the primary driving mechanism is solution-gas drive, among others (Lyons \& Plisga, 2005). 
Table 2 summarizes the oil recovery efficiencies from primary and secondary recovery processes obtained from production data from several reservoirs in the United States.

\begin{tabular}{|c|c|c|c|c|}
\hline & \multicolumn{3}{|c|}{ Recovery Efficiency } & \\
\hline Reservoir Location & $\begin{array}{l}\text { Primary } \\
\% \text { OOIP }\end{array}$ & Type of Secondary Recovery & $\begin{array}{l}\text { Secondary } \\
\% \text { OOIP }\end{array}$ & $\begin{array}{c}\text { Oil Remaining } \\
\% \text { OOIP }\end{array}$ \\
\hline California Sandstones & 26.5 & \multirow{6}{*}{ Pattern Waterfloods } & 8.8 & 64.7 \\
\hline Louisiana Sandstones & 36.5 & & 14.7 & 48.8 \\
\hline Oklahoma Sandstones & 17.0 & & 10.6 & 72.4 \\
\hline Texas Sandstones & 25.6 & & 12.8 & 61.6 \\
\hline Wyoming Sandstones & 23.6 & & 21.1 & 55.3 \\
\hline Texas carbonates & 15.5 & & 16.3 & 68.2 \\
\hline Louisiana Sandstones & 41.3 & \multirow[t]{2}{*}{ Edge Water Injection } & 13.8 & 44.9 \\
\hline Texas carbonates & 34 & & 21.6 & 44.4 \\
\hline California Sandstones & 29.4 & \multirow[t]{2}{*}{ Gas Injection Into Cap } & 14.2 & 56.4 \\
\hline Texas Sandstones & 35.3 & & 8.0 & 56.7 \\
\hline
\end{tabular}

Table 2. Oil Recovery Efficiencies as \% of OOIP from Primary and Secondary Recovery (Adapted from Lyons \& Plisga, 2005).

As Table 2 shows after primary and secondary oil recovery, a significant amount of oil is left behind in the reservoir. Average recovery efficiency data on a worldwide basis indicates that approximatelly one-third of the original oil in place, or less, is recovered by conventional primary and secondary methods (Hirasaki et al., 2011). The efficiency of conventional primary and secondary oil recovery methods can be improved through the implementation of oilfield operations such as infill drilling and the use of horizontal wells, among other improved oil recovery techniques. Figure 4 presents a mind mapping of conventional oil recovery processes.

Tertiary recovery processes refer to the application of methods that aim to recover oil beyond primary and secondary recovery. During tertiary oil recovery, fluids different than just conventional water and immiscible gas are injected into the formation to effectively boost oil production. Enhanced oil recovery (EOR) is a broader idea that refers to the injection of fluids or energy not normally present in an oil reservoir to improve oil recovery that can be applied at any phase of oil recovery including primary, secondary, and tertiary recovery. Thus EOR can be implemented as a tertiary process if it follows a waterflooding or an immiscible gas injection, or it may be a secondary process if it follows primary recovery directly. Nevertheless, many EOR recovery applications are implemented after waterflooding ( Lake, 1989; Lyons \& Plisga, 2005; Satter et al., 2008; Sydansk \& RomeroZerón, 2011). At this point is important to establish the difference between EOR and Improved Oil Recovery (IOR) to avoid misunderstandings. The term Improved Oil Recovery (IOR) techniques refers to the application of any EOR operation or any other advanced oil-recovery technique that is implemented during any type of ongoing oilrecovery process. Examples of IOR applications are any conformance improvement technique that is applied during primary, secondary, or tertiary oil recovery operations. Other examples of IOR applications are: hydraulic fracturing, scale-inhibition treatments, acid-stimulation procedures, infill drilling, and the use of horizontal wells (Sydansk \& Romero-Zerón, 2011). 


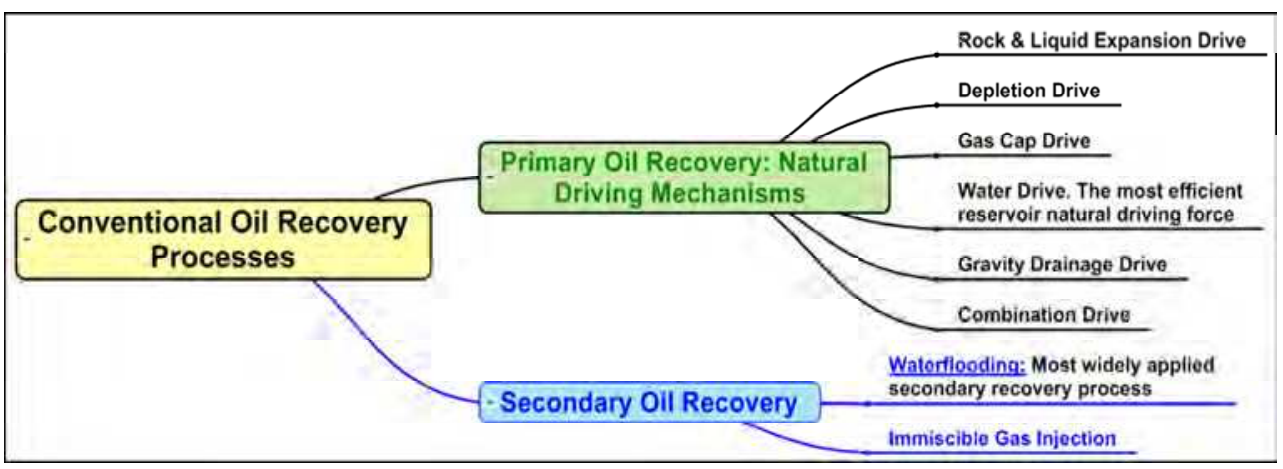

Fig. 4. Summary of Conventional Oil Recovery Processes

\subsection{Enhanced Oil Recovery (EOR) processes}

EOR refers to the recovery of oil through the injection of fluids and energy not normally present in the reservoir (Lake, 1989). The injected fluids must accomplish several objectives as follows (Green \& Willhite, 1998).

- Boost the natural energy in the reservoir

- Interact with the reservoir rock/oil system to create conditions favorable for residual oil recovery that include among others:

- Reduction of the interfacial tension between the displacing fluid and oil

- Increase the capillary number

- $\quad$ Reduce capillary forces

- Increase the drive water viscosity

- Provide mobility-control

- Oil swelling

- Oil viscosity reduction

- Alteration of the reservoir rock wettability

The ultimate goal of EOR processes is to increase the overall oil displacement efficiency, which is a function of microscopic and macroscopic displacement efficiency. Microscopic efficiency refers to the displacement or mobilization of oil at the pore scale and measures the effectiveness of the displacing fluid in moving the oil at those places in the rock where the displacing fluid contacts the oil (Green \& Willhite, 1998). For instance, microscopic efficiency can be increased by reducing capillary forces or interfacial tension between the displacing fluid and oil or by decreasing the oil viscosity (Satter et al., 2008).

Macroscopic or volumetric displacement efficiency refers to the effectiveness of the displacing fluid(s) in contacting the reservoir in a volumetric sense. Volumetric displacement efficiency also known as conformance indicates the effectiveness of the displacing fluid in sweeping out the volume of a reservoir, both areally and vertically, as well as how effectively the displacing fluid moves the displaced oil toward production wells (Green \& Willhite, 1998). Figure 5 presents a schematic of sweep efficiencies: microscopic and macroscopic (areal sweep and vertical sweep). 
The overall displacement efficiency of any oil recovery displacement process can be increased by improving the mobility ratio or by increasing the capillary number or both (Satter et al., 2008). Mobility ratio is defined as the mobility of the displacing fluid (i.e. water) divided by the mobility of the displaced fluid (i.e. oil).

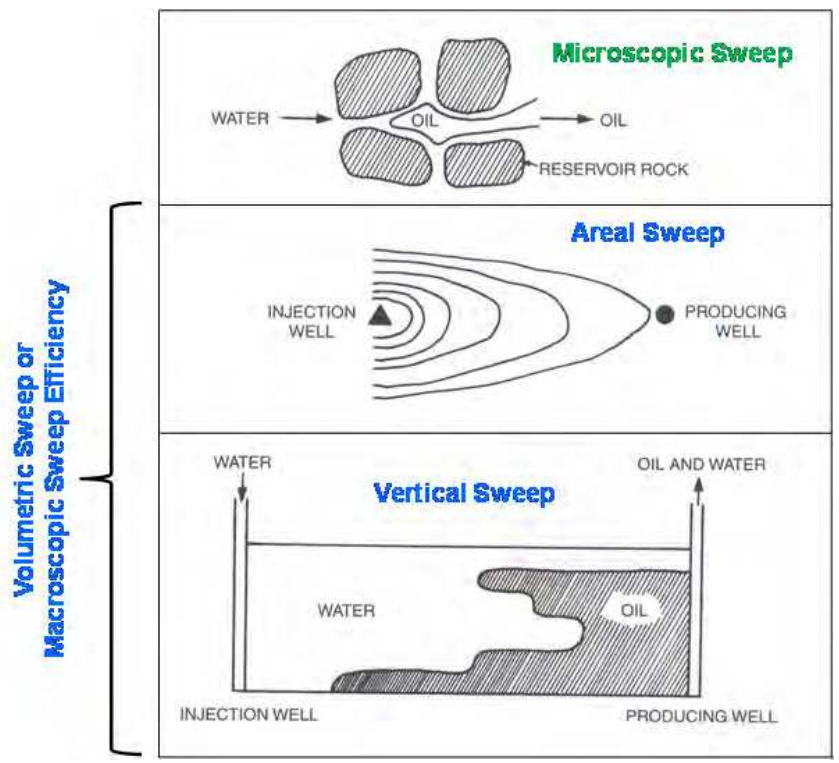

Fig. 5. Schematics of microscopic and macroscopic sweep efficiencies (Lyons \& Plisga, 2005)

For waterfloods, this is the ratio of water to oil mobilities. The mobility ratio, $M$, for a waterflood is given by the following expression:

$$
M=\frac{\text { Mobility }_{\text {Water }}}{\text { Mobility }_{\text {Oil }}}=\frac{\lambda_{w}}{\lambda_{o}}=\frac{k_{r w} / \mu_{w}}{k_{r o} / \mu_{o}}=\frac{k_{r w} \mu_{o}}{k_{r o} \mu_{w}}
$$

where $\lambda_{\mathrm{w}}$ and $\lambda_{o}$ are water and oil mobilities, respectively, in md/cp; $k_{\mathrm{rw}}$ and $k_{\mathrm{ro}}$ are relative permeabilities to water and oil, respectively, is $\mu_{\mathrm{o}}$ oil viscosity and $\mu_{\mathrm{w}}$ is water viscosity (Lyons \& Plisga, 2005).

Volumetric sweep efficiency increases as $M$ decreases, therefore mobility ratio is an indication of the stability of a displacement process, with flow becoming unstable (nonuniform displacement front or viscous fingering) when $\mathrm{M}>1.0$. Thus, a large viscosity contrast between the displacing fluid (i.e. water) and the displaced fluid (i.e. oil) causes a large mobility ratio (unfavorable $M$ ) which promotes the fingering of water through the more viscous oil (Fig. 6) and reduces the oil recovery efficiency. As such mobility ratio can be improved by increasing the drive water viscosity using polymers.

The capillary number, $N_{c}$, is a dimensional group expressing the ratio of viscous to capillary (interfacial) forces as follows: 


$$
N_{c}=\frac{\text { viscous forces }}{\text { capillary forces }}=\frac{v \mu_{w}}{\sigma_{o w}}
$$

where $v$ is the interstitial velocity of the displacing fluid (i.e. water), $\mu_{\mathrm{w}}$ is the viscosity of the displacing fluid (i.e. water), and $\sigma_{\mathrm{ow}}$ is the interfacial tension between the oil and the displacing fluid. Capillary numbers for a mature waterflooding process are commonly in the order of $10^{-7}$ to $10^{-6}$ (Green \& Willhite, 1998). At the end of the waterflooding process, experience has shown that at these low capillary numbers an important amount of oil is left behind in the reservoir trapped by capillary forces at the pore scale. Thus, if the capillary number is increased through the application of EOR processes, residual oil will be mobilized and recovered. The most practical alternative to significantly increase the capillary number is through the application of surfactants or alkaline flooding (chemical flooding) (Sydansk \& Romero-Zerón, 2011).

EOR processes are classified in five general categories: mobility-control, chemical, miscible, thermal, and other processes, such as microbial EOR (Green \& Willhite, 1998). Figure 7 shows this EOR classification in more detail.

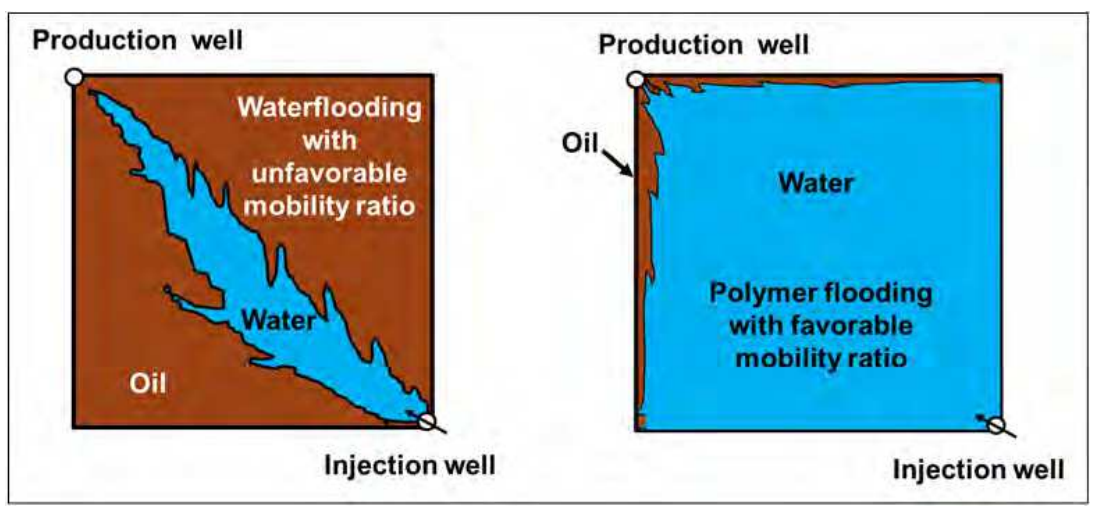

Fig. 6. (a) Waterflooding with unfavorable mobility ratio (M>1), (b) Polymer augmented waterflooding with favorable mobility ratio $(M \leq 1)$ (Sydansk \& Romero-Zerón, 2011).

A typical EOR fluid injection sequence is presented in Fig. 8. Some of the requirements for the ideal EOR flooding include among others (Singhal, 2011):

- Appropriate propagation of fluids and/or chemicals (i.e. polymers or surfactants) deep inside the reservoir rock.

- Low or minimum chemical adsorption, mechanical entrapment, and chemical consumption onto the formation rock.

- $\quad$ Fluids and/or chemicals tolerance to formation brine salinity and hardness.

- Fluids and/or chemicals stability to high reservoir temperatures.

- Polymers stability to mechanical degradation.

- Advanced polymer mobility-control to improve sweep efficiency.

- Efficient reductions of interfacial tension between oil and water. 


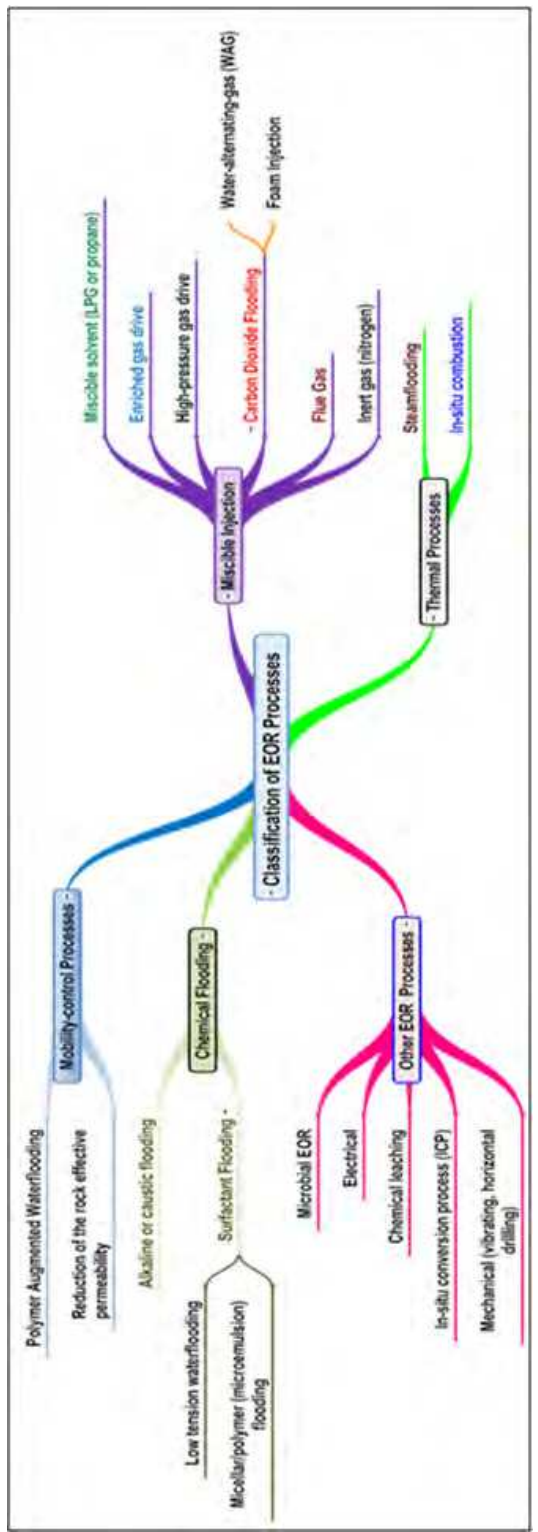

Fig. 7. Classification of Enhanced Oil Recovery Processes (Lake, 1989; Lyons \& Plisga, 2005)

Although, EOR has been practiced for decades, and the petroleum industry has actively cooperated towards the advancement of EOR technology, there are still several challenges to the implementation of EOR projects that must be overcome. In the subsequent paragraphs a brief description of each EOR process is given with emphasis on the emerging technological trends. 


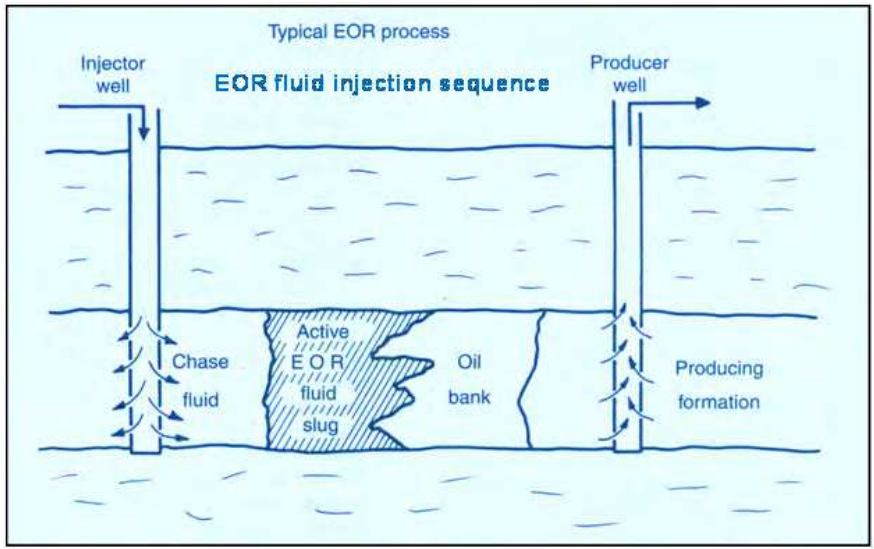

Fig. 8. Common EOR fluid injection sequence (Source: Lyons \& Plisga, 2005)

\subsubsection{Mobility-control processes}

High mobility ratios cause poor displacement and sweep efficiencies, which can be caused by a large viscosity contrast between the displacing fluid (i.e. water) and oil or by the presence of high permeability flow channels that result in early breakthrough of the displacing fluid (i.e. water) at the producer well (Lyons \& Plisga, 2005). Large volumes of produced water significantly increase operational costs due to water handling and the disposal of water according to the environmental regulations in place. According to Okeke \& Lane, (2012), on average, it is estimated that seven barrels of water are produced per barrel of oil in the U.S.A., and the associated treatment and disposal cost is estimated around \$ 5-10 billion annually. There are two techniques that can be applied within the oilreservoir rock to successfully control volumetric sweep and/or conformance problems as follows (Sydansk \& Romero-Zerón, 2011).

- Polymer flooding: consist in increasing the viscosity of the oil-recovery drive fluid.

- Gels or crosslinked polymers: consist in the placement of permeability-reducing material in the offending reservoir high-permeability flow channels.

\subsubsection{Polymer flooding}

Polymer flooding or polymer augmented waterflooding consist of adding water-soluble polymers to the water before it is injected into the reservoir. Polymer flooding is the simplest and most widely used chemical EOR process for mobility control (Pope, 2011). The most extensively used polymers are hydrolyzed polyacrylamides (HPAM) and the biopolymer Xanthan. Normally low concentrations of polymer are used often ranging from 250 to $2,000 \mathrm{mg} / \mathrm{L}$ and the polymer solution slug size injected is usually between $15 \%$ to $25 \%$ of the reservoir pore volume (PV). For very large field projects, polymer solutions may be injected over a 1-2 year period of time; after wich the project reverts to a normal waterflood. Incremental oil recovery is on the order of $12 \%$ of the original oil in place (OOIP) when polymer solution is injected for about one pore volume and values as high as $30 \%$ OOIP have been reported for some field projects (Pope, 2011). Furthermore, the displacement is more efficient in that less injection water is required to produce a given 
amount of oil (Lyons \& Plisga, 2005; Sydansk, 2007). To produce an incremental barrel of oil, about 1 to $2 \mathrm{lbs}$ of polymer are required, which means that currently the polymer cost is approximately USD $1.5 / \mathrm{bbl}$ to USD $3 / \mathrm{bbl}$. The affordable price of polymer compared to the price of oil, explains why presently, the number of polymer flooding projects is increasing exponentially; for instance, in the U.S.A approximatelly 1 billion lbs of polymer was used in 2011 for mobility-control EOR (Pope, 2011). Mobility-control performance of any polymer flood within the porous media is commonly measured by the resistance factor, (RF), which compares the polymer solution resistance to flow (mobility) through the porous media as compared to the flow resistance of plain water. As exemplified by Lyons \& Plisga (2005), if a RF of 10 is observed, it is 10 times more difficult for the polymer solution to flow through the system, or the mobility of water is reduced 10 -fold. As water has a viscosity around $1 \mathrm{cP}$, the polymer solution, in this case, would flow through the porous system as though it had an apparent or effective viscosity of $10 \mathrm{cP}$ even though a viscosity measured in a viscometer could be considerably lower. Figure 9 presents a mind map of the mechanisms, limitations, and problems linked to polymer flooding applications.

\subsection{Polymer flooding: emerging trends}

The emerging technological trends in polymer flooding include the development of temperature and salinity resistant polymers (i.e. Associative polymers or hydrophobically modified polymers), high-molecular weight polymers, the injection in the reservoir of larger polymer concentrations, and the injection of larger slugs of polymer solutions (Aladasani \& Bai, 2010; Dupuis et al. 2010, 2011; Lake, 2010; Pope, 2011; ReichenbachKlinke et al., 2011; Seright et al. 2011; Sheng, 2011; Singhal, 2011; Sydansk \& RomeroZerón, 2011; Zaitoun et al., 2011) among others. Figure 10 summarizes the emerging trends in polymer flooding.

\subsubsection{Polymers or polymer gel systems}

Permeability-reducing materials can be applied from both the injection-well and the production-well side. There are a variety of materials that can be used for this purpose including polymer gels, resins, rigid or semi-rigid solid particles, microfine cement, etc. In this chapter the attention is focused on polymers or polymer gel systems.

Relative-Permeability-Modification (RPM) water-shutoff treatments, also termed Disproportionate Permebility Reduction (DPR) treatments are water-soluble polymer systems and weak gels that reduce the permeability to water flow to a greater degree than to oil and gas flow (Sydansk \& Seright, 2007); particularly in wells where water and oil are produced from the same zone and the water-bearing cannot easily be isolated. These systems perform due to adsorption onto the pore walls of the formation flow paths (Chung et al., 2011). Several mechanisms for RPM have been proposed, including changes in porous media wettability, lubrication effects, segregation of flow pathways, gel dehydration, and gel displacement, among others (Sydansk \& Romero-Zerón, 2011). However, there is no agreement upon a definite mechanism or mechanisms responsible for RPM, the most accepted mechacnism is gel dehydration (Seright et al., 2006). Therefore, this topic remains a subject under active investigation. The outcome of RPM oilfield applications has been mixed and the magnitude of the effect of RPM has been unpredictable from one application to another (Chung et al., 2011, Sydansk \& Romero-Zerón, 2011). 
Polymer gel systems are formed when low concentrations of a water-soluble highmolecular-weight polymer reacts with a chemical crosslinking agent to form a 3D crosslinked-polymer network that shows solid-like properties with rigidities up to and exceeding that of Buna rubber. In oilfield applications, polymer gels contain polymer concentrations ranging from 1,500 ppm to $12,000 \mathrm{ppm}$ and gels are injected into the reservoir as a "watery" gelant (pre-gel) solution, or as a partially formed gel; after the gelation-onset time for the particular gel at reservoir conditions, the gelant solution (or partially formed gel) matures and sets up in the reservoir acquiring solid-like properties. Gelant solution must be pumped at very low rates to preferentially flow into the water channels, reducing the invation of gelant into the matrix rock containing oil (Chung et al., 2011).

Chromium (III)-Carboxylate/Acrylamide-Polymer (CC/AP) gels are the most popular and widely applied polymer-gel technology as mobility control treatments and as water and gas-shutoff treatments. These CC/AP gels are produced by croslinlinking aqueous soluble acrylamide-polymers with chromium (III) carboxylate or chromic triacetate ( $\left.\mathrm{CrAc}_{3}\right)$. Depending on the particular oilfield application, the gelation reaction rate can be accelerated or retarded by adding the proper chemical agents or combination of chemicals. For instance, chromic trichloride can be used as an additive to accelarate the CC/AP gelation reaction. If the $\mathrm{CC} / \mathrm{AP}$ are applied to high-temperature reservoirs, it may be necessary to delay the gelation-rate. In this situation, the gelation-rate is slowed down by using gelation-rate retardation agents such as carboxylate ligands (i.e. lactate), the use of ultra-low-hydrolysis polyacrylamides within the gel formulation, and the use of low molecular weight (MW) acrylamide polymers. The proper application of gel treatments can generate in a profitable manner large volumes of incremental oil production and/or substantial reductions in oilproduction operating costs via the shutting off of the production of excessive non-oil fluids, such as water and gas (Norman, et al. 2006; Sydansk \& Romero-Zerón, 2011). A summary of the mechanisms, benefits, limitations, and problems eoncountered during oilfield applications of CC/AP gels is presented in Fig. 11.

\subsection{Gels or crosslinked polymers: emerging trends}

Some of the emerging trends in polymer gels or similar permeability-reducing materials that are under development include: thermally expandable particulate material, $\mathrm{pH}$ sensitive polymers, colloidal dispersion gels (CDGs), nano-size microgels, organically crosslinked polymer (OCP) systems, and preformed particle gel technologies, among others.

- Thermally expandable particulate material. This technology, which is still under development and field testing, is based on the expansion of thermally sensitive microparticles which can be used to cause blocking effect at the temperature transition in an oil reservoir. The polymeric material is a highly crosslinked, sulfonate-containing polyacrylamide microparticles in which the conformation is constrained by both unstable and stable internal crosslinks. As the particles reach areas of elevated temperatures within the reservoir, decomposition of the unstable crosslinker takes place releasing the constrains on the polymer molecule(s) in the particle allowing absorption of water and re-equilibration to render a larger particle size that provides resistance to fluid flow in porous media. The fluid flow blocking activity of the expanded polymeric particles in the porous media include particle/wall interactions, particle/particle 


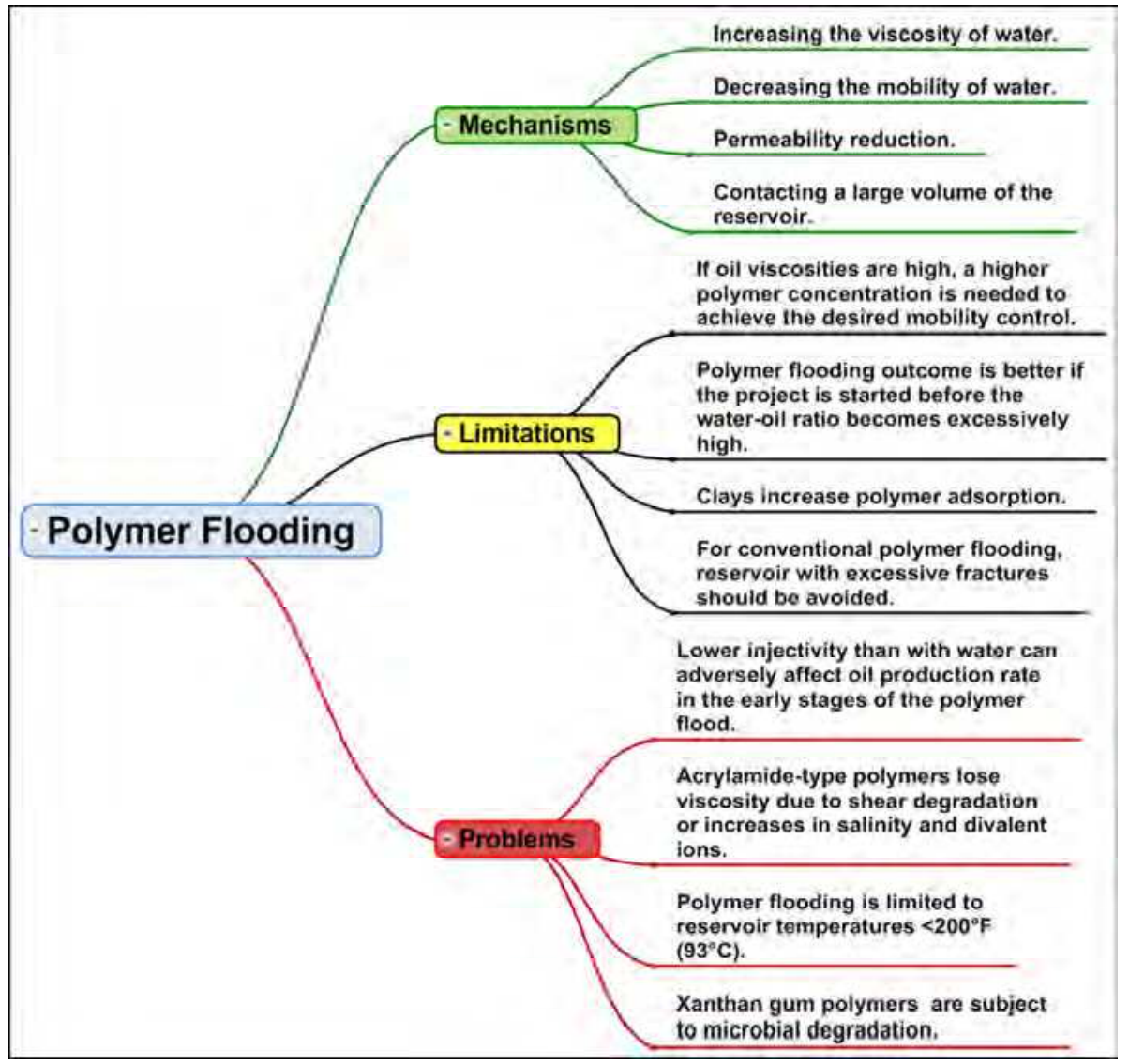

Fig. 9. Polymer Flooding: mechanisms, limitations, and problems (Adapted from Lyons \& Plisga, 2005).

interactions, and bridging (Garmeh, et al. 2011; Frampton, et al,. 2004). Critical parameters that affect the application of this technology in the field were recently evaluated by Izgec \& Shook (2012). The oilfield application of this technology is still at the evaluation stage. Some oilfield trial applications are presented by Mustoni et al. (2010); Ohms et al. (2010); and Roussennac \& Toschi (2010). Independent technical and economic comparative analyses between this thermally activated polymeric material for in-depth profile modification and conventional polymer flooding conducted by Okeke \& Lane, (2012) and Seright et al. (2011) concluded that in the long-term a properly design polymer flood program is advantageous over the application of thermally activated deep diverting materials. 


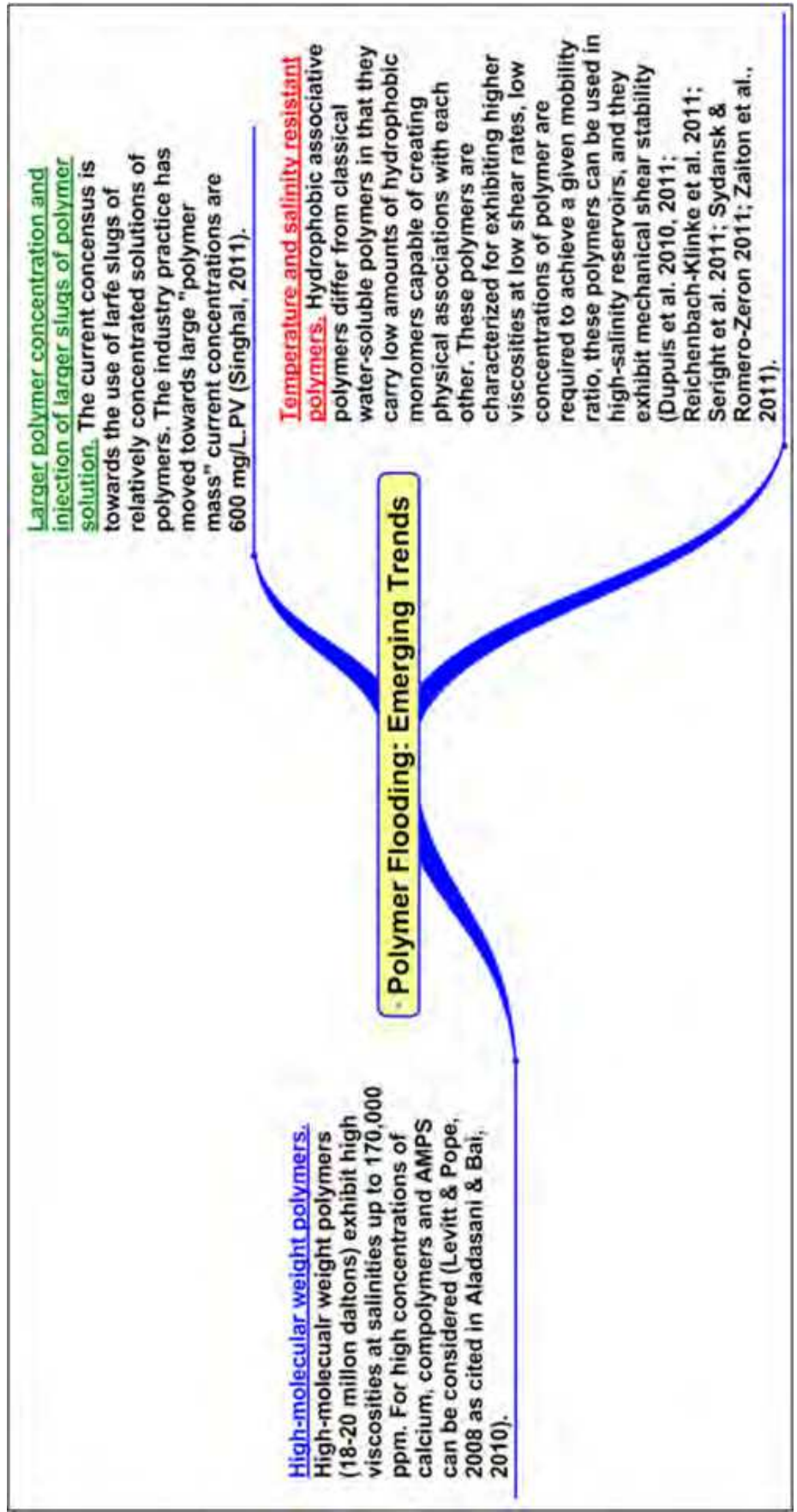

Fig. 10. Polymer Flooding: Emerging Trends 


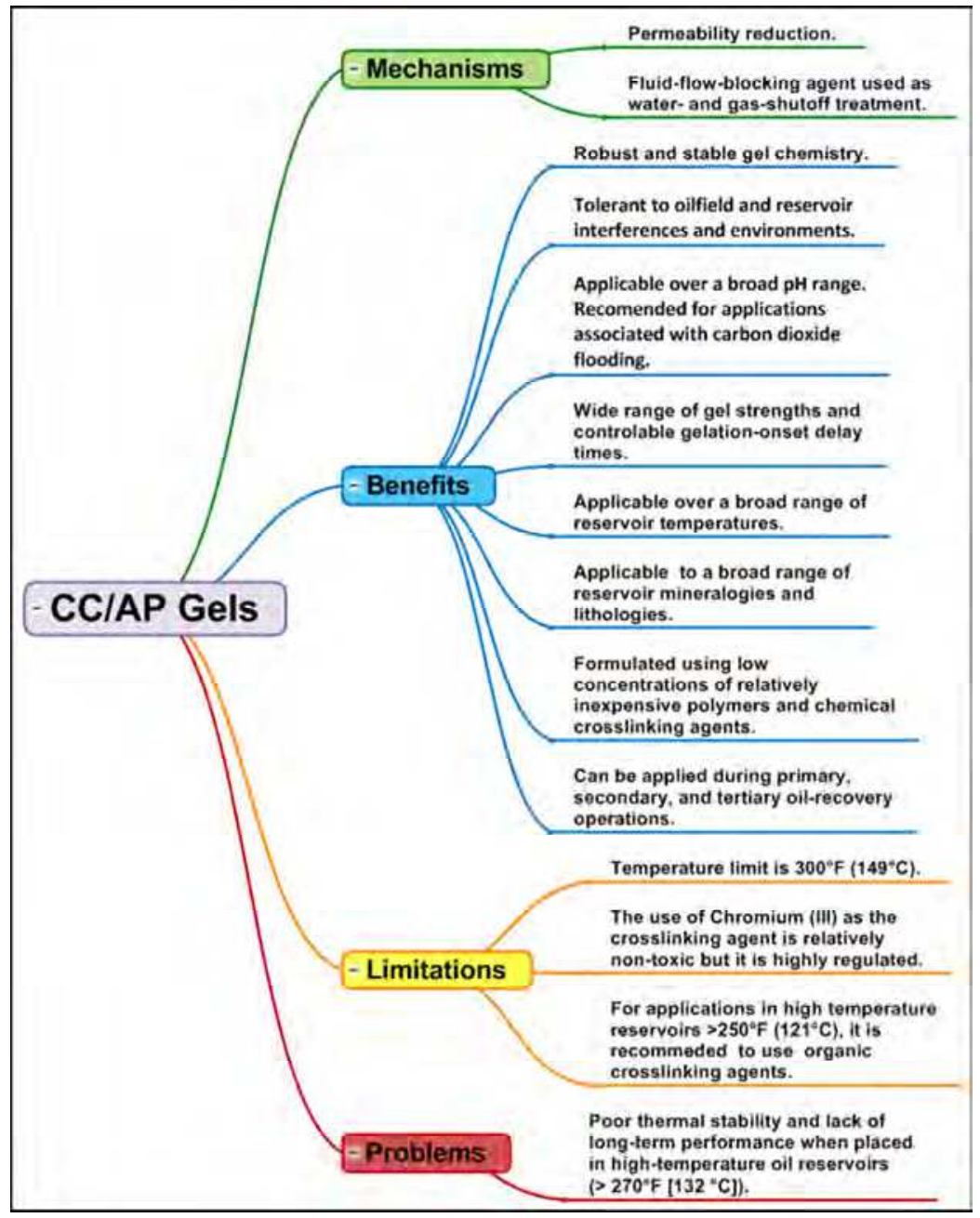

Fig. 11. CC/AP Gels: mind map of the mechanisms, benefits, limitations, and problems encountered during oilfield applications of CC/AP gels (Lyons \& Plisga, 2005; Sydansk \& Romero-Zerón, 2011).

- $\quad$ HH Sensitive Polymers. This technology aims the use of low-cost, pH-triggered polymer to improve reservoir sweep efficiency and reservoir conformance in chemical flooding. The idea is to use polymers or microgels containing carboxyl functional groups to make the polymer viscosity $\mathrm{pH}$ dependent. Thus, the polymer or microgel solution is injected into the reservoir at low $\mathrm{pH}$ conditions, in which the polymer molecules are in an unswelled tightly-coiled state and the viscosity is low, so that the polymer and/or microgel solution flows through the near wellbore region with a relatively low pressure drop avoiding the generation of unwanted fractures near the wellbore. Away from the near wellbore region, at a neutral $\mathrm{pH}$ the polymer and/or 
microgel solution swells and becomes thickened by a spontaneous reaction between the injected polymer acid solution and the resident rock mineral components thus, lowering the brine mobility and increasing oil displacement efficiency (Choi, 2005; Choi et al., 2006; Huh et al. 2005; Lalehrokh, 2009; Sharma et al., 2008).

- Colloidal Dispersion Gels (CDGs). As defined by Fielding et al. (1994), CDG is a solution containing low concentrations of high molecular weight polymer and a crosslinker that has a slow rate of formation and is considered semi-fluid. The CDGs microgels are injected from the injection-well side for the purpose of improving vertical and areal conformance deep in heterogeneous "matrix-rock" of sandstone reservoirs, while maintaining high temperature stability. CDG gels flow a highpressure differentials and resist flow at low-pressure differentials (Fielding et al. 1994). Although numerous publications (Chang et al. 2004; Diaz et al. 2008; Fielding et al. 1994; Lu et al. 2000; Muruaga et al. 2008; Norman et al. 1999; Shi et al. 2011a, 2011b; Smith et al. 1996; Smith et al. 2000; Spildo et al. 2008) have discussed over the years the effectiveness of CDGs through laboratory studies and field trials, this technology has proven to be controversial ( Al-Assi et al,. 2006; Ranganathan et al., 1998; Seright, 2006; Sydansk \& Romero-Zerón, 2011; Wang et al., 2008).

- Nano-size Microgels. Recently Wang et al. (2010) proposed the use of crosslinked polyacrylamide (PAM) nanospheres for in-depth profile control to improve sweep efficiency. It is speculated that owing to the nano size, water absorbing selectivity, brine tolerance, high water absorption, good dispersion in water, low aqueous solution viscosity, nanospheres can easily migrate into the high-permeability zones (channels of low-resistance to flow) where the nanospheres would swell due to their high water absorption capacity blocking off the thief zones.

- Organically crosslinked polymer (OCP) systems. These systems are based on PEI (polyethyleneimine) crosslinker with a copolymer of acrylamide and $t$-butyl acrylate (PAtBA) for in-depth profile control. The main advantage of this crosslinker is its lower toxicity while the low molecular weight copolymer PAtBA enhances the biodegradability of the material and facilitates the formation of thermally stable, rigid gels that are insensitive to formation fluids, lithology, and/or heavy metals. Numerous field trials have been conducted worldwide (Chung et al., 2011).

- $\quad$ Preformed Particle Gels (PPGs). PPGs consist on crushed dry gels that are sieved to obtain different cuts of gel particles, which swell in water and form a stable suspension that flows within the porous media. These diverting agents aim to provide in-depth fluid diversion (Coste et al., 2000). PPGs are currently gaining attention and popularity for use in conformance-improvement treatments. Bai et al. (2009) reported an extensive review of PPGs for conformance control that covers from PPGs mechanisms to field applications. Recently a new PPG enhanced surfactant-polymer system has been proposed by Cui, et al. (2011).

\subsubsection{Chemical flooding}

Chemical flooding is a generic term for injection processes that use special chemicals (i.e. surfactants) dissolved in the injection water that lower the interfacial tension (IFT) between the oil and water from an original value of around 30 dynes $/ \mathrm{cm}$ to $10^{-3}$ dynes $/ \mathrm{cm}$; at this low IFT value is possible to break up the oil into tiny droplets that can be drawn from the 
rock pores by water (Van Dyke, 1997). There are two common chemical flooding: micellarpolymer flooding and alkaline or caustic flooding.

\subsubsection{Micellar-polymer flooding}

Micellar-polymer flooding is based on the injection of a chemical mixture that contains the following components: water, surfactant, cosurfactant (which may be an alcohol or another surfactant), electrolytes (salts), and possible a hydrocarbon (oil). Micellar-polymer flooding is also known as micellar, microemulsion, surfactant, low-tension, soluble-oil, and chemical flooding. The differences are in the chemical composition and the volume of the primary slug injected. For instance, for a high surfactant concentration system, the size of the slug is often 5\%-15\% pore volumes (PV), and for low surfactant concentrations, the slug size ranges from $15 \%-50 \%$ PV. The surfactant slug is followed by polymer-thickened water. The concentration of polymer ranges from $500 \mathrm{mg} / \mathrm{L}$ to $2,000 \mathrm{mg} / \mathrm{L}$. The volume of the polymer solution injected may be $50 \%$ PV, depending on the process design (Green \& Willhite, 1998; Satter et al., 2008). Flaaten et al. (2008) reported a systematic laboratory approach for chemical flood design and applications. Some of the main surfactant requirements for a successful displacement process are as follows (Hirasaki et al., 2011).

- $\quad$ The injected surfactant slug must achieve ultralow IFT (IFT in the range of 0.001 to 0.01 $\mathrm{mN} / \mathrm{m}$ ) to mobilize residual oil and create an oil bank where both oil and water flows as continuous phases.

- It must maintain ultralow IFT at the moving displacement front to prevent mobilized oil from being trapped by capillary forces.

- Long-term surfactant stability at reservoir conditions (temperature, brine salinity and hardness).

Figure 12 summarizes the mechanisms, limitations, and problems eoncountered during micellar-polymer flooding projects.

\subsubsection{Alkaline or Caustic flooding}

In this type of chemical flooding, alkaline or caustic solutions are injected into the reserovoir. Common caustic chemicals are sodium hydroxide, sodium silicate, or sodium carbonate. These caustic chemicals react with the natural acids (naphtenic acids) present in crude oils to form surfactants in-situ (sodium naphthenate) that work in the same way as injected synthetic surfactants (reduction of interfacial tension, IFT, between oil/water) to move additional amounts of oil to the producing well. These chemicals also react with reservoir rocks to change wettability. Alkaline flooding can be applied to oils in the API gravity range of $13^{\circ}$ to $35^{\circ}$, particulary in oils having high content of organic acids. The preferred oil formations for alkaline flooding are sandstone reservoirs rather than carbonate formations that contain anhydride or gypsum, which can consume large amounts of alkaline chemicals. These chemicals are also consumed by clays, minerals, or silica, and the higher the temperature of the reservoir the higher the alkali consumption. Another common problem during caustic flooding is scale formation in the producing wells. During alkaline flooding, the injection sequence usually includes: (1) a preflush to condition the reservoir before injection of the primary slug, (2) primary slug (alkaline chemicals), (3) polymer as a mobility buffer to displace the primary slug. Modifications of alkaline flooding are the alkali-polymer (AP), alkali-surfactant (AS), and alkali-surfactant-polymer (ASP) processes (Green \& Willhite, 1998; Satter et al., 2008; Van Dyke, 1997). In addition to the beneficial formation of natural 


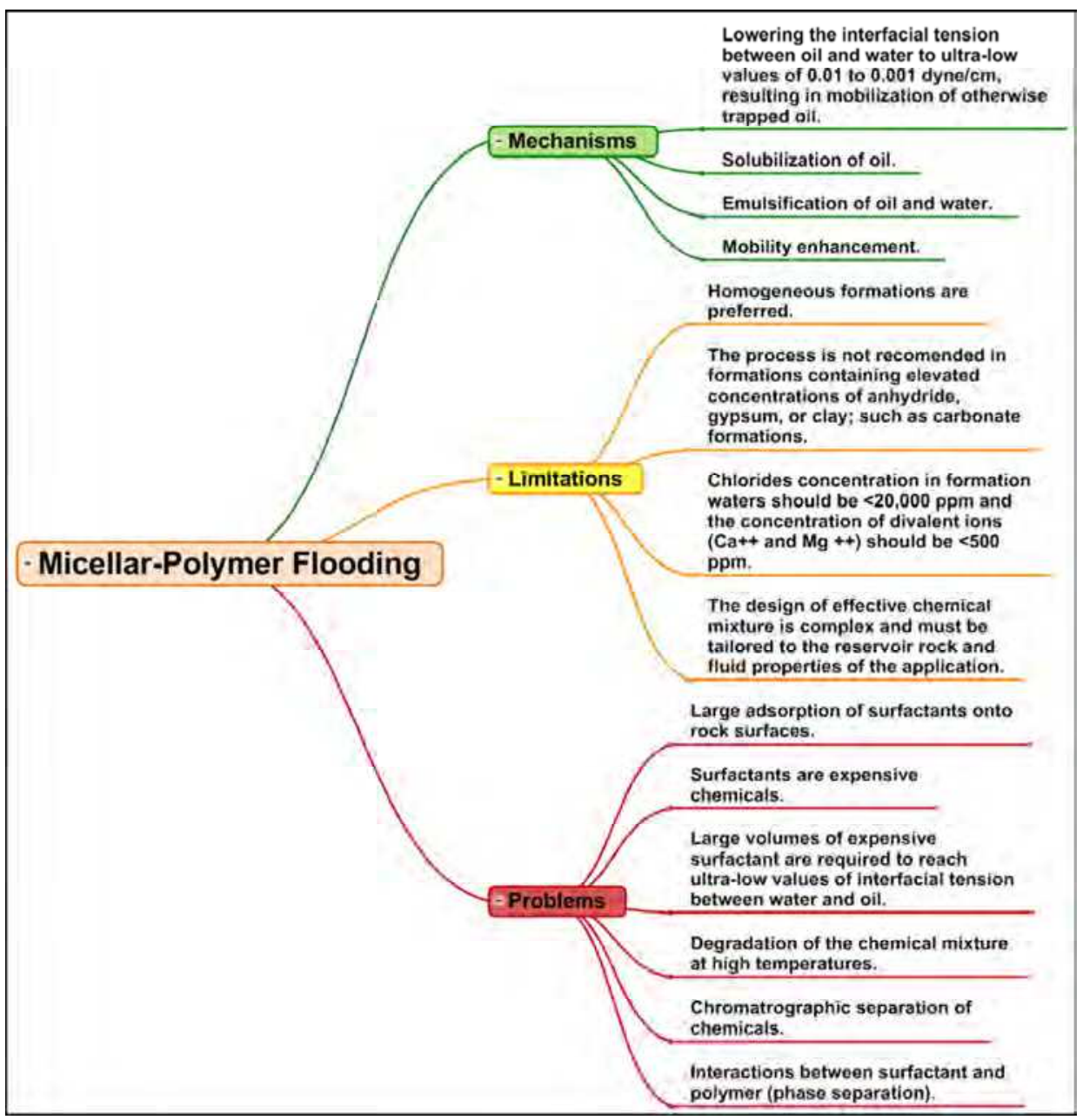

Fig. 12. Micellar-Polymer Flooding: mechanisms, limitations, and problems (Adapted from Feitler, 2009; Lyons \& Plisga, 2005; Satter et al., 2008).

surfactants (surfactants in-situ) driven by the reaction of alkali with naphtenic acids in the crude oil, the role of the alkali in the AS and ASP processes is to reduce the adsorption of the surfactant during displacement through the formation and sequestering of divalents ions. The presence of alkali can also alter formation wettability to reach either more water-wet or more oil-wet states. For instance, in fractured oil-wet reservoirs, the combined effect of alkali and surfactant in making the matrix preferentially water-wet is essential for an effective process. These benefits of alkali will occur only when alkali is present (Hirasaki et al., 2011). Jackson (2006) reported a detailed experimental study of the benefits of sodium carbonate on 
surfactants for EOR. Surfactants are also used to change the wettability of the porous media to boost oil recovery. Wu et al., (2006) reviewed the mechanisms responsible for wettability changes in fractured carbonate reservoirs by surfactant solutions.

Micellar-polymer flooding was considered a promising EOR process during the 1970s, however the high surfactant concentrations required in the process and the cost of surfactants and cosurfactants, combined with the low oil prices during the mid 1980s limited its applications. Worldwide, oilfield applications of chemical flooding have been insignificant since the 1990s (Hirasaki et al., 2011; Manrique, et al. 2010) and although practiced, is rarely reported by operators (Enick \& Olsen, 2012). The main reason is again the dependance of chemical flooding processes on the volatility of the oil markets because these processes are capital intensive and carry a high degree of risk (Bou-Mikael et al. 2000). Nevertheless, the development of both SP and ASP EOR technology and advances on surfactant chemistry during the last 5 years have brought a renewed attention for chemical floods (Pope, 2011), specially to boost oil production in mature and waterflooded fields. Currently, there are numerous active ASP flooding projects worldwide, with the ASP flooding implemented at the Daqing field in China considered one of the largest ASP ongoing projects (Manrique et al. 2010). Several current ASP oilfield applications are reported in the literature (Buijse et al., 2010; Manrique et al. 2010).

\subsubsection{Chemical flooding: emerging trends}

In the area of micellar-polymer flooding, the emerging trends are related to the development of surfactant systems having the following capabilities (Adkins et al., 2010; Azira et al., 2008; Banat et al., 2000; Barnes et al., 2010; Berger \& Lee, 2002; Cao \& Li, 2002; Elraies et al., 2010; Feitler, 2009; Flaaten et al., 2008; Hirasaki et al., 2011; Iglauer et al., 2004; Levitt, 2006; Levitt et al., 2009; Ovalles et al., 2001; Puerto et al., 2010; Sheng, 2011; Yang et al., 2010; Wang et al., 2010; Wu et al., 2005):

- Reduce the oil-water interfacial tension to ultra-low values (0.01-0.001 dyne/cm) at low surfactant concentrations $(<0.1 \mathrm{wt} \%)$ to significantly reduce the amount of expensive surfactant used in oil recovery.

- Production of low cost surfactants.

- Development of surfactants active only upon contact with hydrocarbon fluids.

- The reduction or minimization of surfactant loss due to adsorption on rock surface.

- Development of single-phase injection composition systems (no phase separation when polymer is present).

- Development of mechanistic chemical flood simulators useful for the designing and performance prediction of EOR processes.

- The evaluation and development of novel alkalis.

- Advances of protocols for surfactant selection, laboratory testing, and scaling up of laboratory data to the field (Pope, 2011).

Some of the best surfactants presently available have molecular weights 10 times larger than the surfactants previously used and the surfactant molecule is highly branched, which minimizes the surfactant adsorption onto both sandstones and carbonates. Furthermore, these new surfactants are up to three times more efficient in terms of oil recovery per pound of surfactant (Pope, 2011). A brief review on new polymeric surfactants for EOR is presented in Chapter 2. Figure 13 summarizes recent advances in chemical flooding technology. 


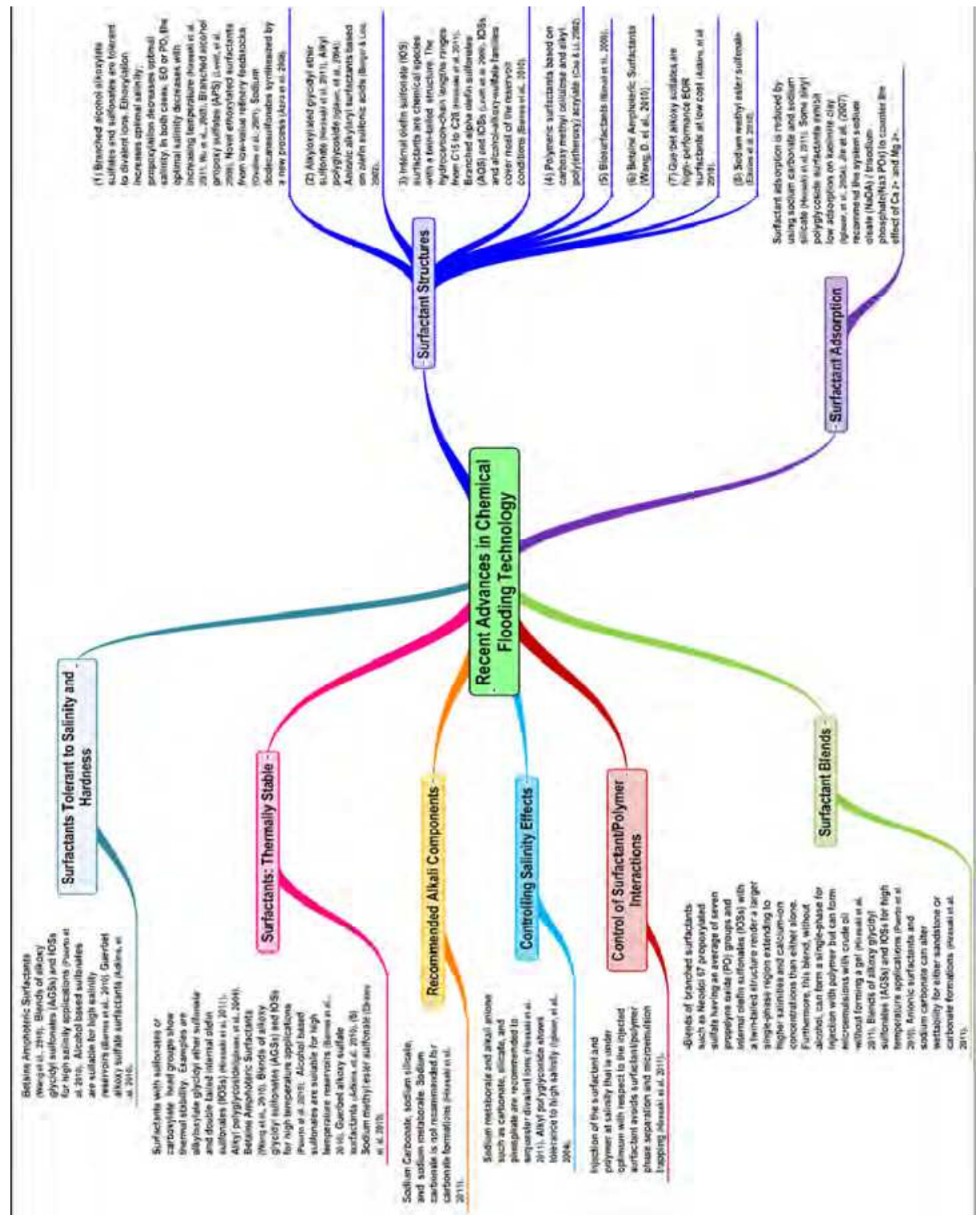

Fig. 13. Recent Advances in Chemical Flooding Technology.

\subsubsection{Miscible injection}

Miscible injection uses a gas that is miscible (mixable) with oil and as the gas injection continues, the gas displaces part ot the oil to the producing well. Injection gases include liquefied petroleum gases (LPGs) such as propane, methane under high pressure, methane enriched with light hydrocarbons, nitrogen under high pressure, flue gas, and carbon 
dioxide used alone or followed by water. LPGs are appropriate for use in many reservoirs because they are miscible with crude oil on first contact. However, LPGs are in such demand as marketable commodity that their use in EOR is limited (Van Dyke, 1997). As presented by Lyons \& Plisga (2005), the mechanisms of oil recovery by hydrocarbon miscible flooding are:

- Miscibility generation

- Increasing the oil volume (swelling)

- Decreasing the viscosity of the oil

Limitations of hydrocarbon miscible flooding are the reservoir pressure needed to maintain the generated miscibility. Pressures required range from 1,200 psi for the LPG process to 5,000 psi for the high pressure methane or lean gas drive. For these applications a steeply dipping (not flat-lying) formation is preferred to allow gravity stabilization of the displacement, which normally has an unfavorable mobility ratio. The main problems associated to hydrocarbon miscible flooding are poor vertical and horizontal sweep efficiency due to viscous fingering, large quantities of expensive gases are required, and solvent may be trapped and not recovered (Lyons \& Plisga, 2005). Hydrocarbon gas injection projects have made a relatively marginal contribution in terms of total oil recovered in Canada and U.S.A. other than on the North Slope of Alaska where large natural gas resources are available for use that do not have a transportation system to markets. Generally, hydrocarbon miscible flooding is applied in water-alternating-gas (WAG) injection schemes (Manrique et al. 2010). Injection of flue gas $\left(\mathrm{N}_{2}, \mathrm{CO}_{2}\right)$ and $\mathrm{N}_{2}$ had essentially been replaced by $\mathrm{CO}_{2}$ since the 1980 s. While, EOR from miscible $\mathrm{CO}_{2}$ floods has been steadily increasing over the last two decades, as has the number of projects. Currently, $\mathrm{CO}_{2}$ EOR provides about 280,000 barrels of oil per day, just over $5 \%$ of the total U.S.A. crude oil production. Recently $\mathrm{CO}_{2}$ flooding has become so technically and economically attractive that $\mathrm{CO}_{2}$ supply, rather than $\mathrm{CO}_{2}$ price, has been the constraining developmental factor. $\mathrm{CO}_{2} \mathrm{EOR}$ is likely to expand in the U.S.A. in the near future due to "high" crude oil prices, natural $\mathrm{CO}_{2}$ source availability, and possible large anthropogenic $\mathrm{CO}_{2}$ sources through carbon capture and storage (CCS) technology advances. It is estimated that in the U. S. A., the "next generation" $\mathrm{CO}_{2} \mathrm{EOR}$ can provide 137 billion barrels of additional technically recoverable domestic oil (Enick \& Olsen, 2012).

$\mathrm{CO}_{2}$ flooding is carried out by injecting large quantities of $\mathrm{CO}_{2}(15 \%$ or more of the hydrocarbon pore volume, PV) into the reservoir. Typically it takes about $10 \mathrm{Mcf}$ of $\mathrm{CO}_{2}$ to recover an incremental barrel of oil and about half of this gas will be left in the reservoir at the economic limit (Pope, 2001). Although $\mathrm{CO}_{2}$ is not truly miscible with the crude oil, $\mathrm{CO}_{2}$ extracts the light-to-intermediate components from the oil, and, if the pressure is high enough, develops miscibility to displace the crude oil from the reservoir (Lyons \& Plisga, 2005). Basically, during $\mathrm{CO}_{2}$ displacements miscibility takes place through in-situ composition changes resulting from mutliple-contacts and mass transfer between reservoir oil and the injected $\mathrm{CO}_{2}$ (Green \& Willhite, 1998). $\mathrm{CO}_{2}$ has a greater viscosity under pressure than many other gases and displaces oil at low pressures (Van Dyke, 1997). Figure 14 summarizes the mechanisms, limitations, and main downsides of $\mathrm{CO}_{2}$ flooding. 
To overcome mobility control during $\mathrm{CO}_{2}$ flooding, the current technologies of choice are the use of water-alternating-gas (WAG) injection schemes and mechanical techniques including cement, packers, well control, infield drilling, and horizontal wells (Enick \& Olsen, 2012).

$\mathrm{CO}_{2}$ flooding has been the most widely used EOR recovery method of medium and light oil production in sandstone reservoirs during recent decades, especially in the U.S.A., due to the availability of cheap and readily available $\mathrm{CO}_{2}$ from natural resources such as the Permian Basin (Pope, 2011). It is expected that $\mathrm{CO}_{2}$ floods will continue to grow globally in sandstone and carbonate reservoirs (Manrique et al. 2010). Furthermore, the pressing issue of sequestering considerable volumes of industrial $\mathrm{CO}_{2}$ due to environmental concerns would play an importan role in the grow of miscible $\mathrm{CO}_{2}$ oilfield applications. Several $\mathrm{CO}_{2}-$ EOR field projects are described by Enick \& Olsen, (2012) and Manrique et al. (2010).

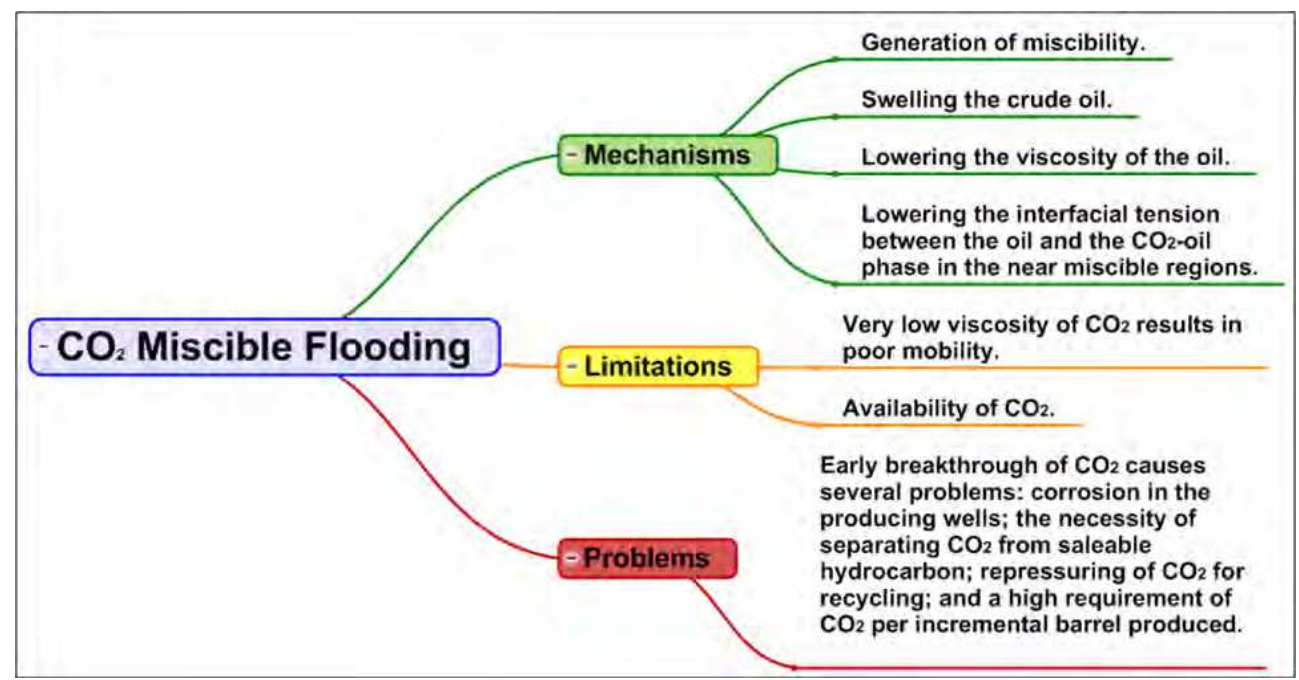

Fig. 14. $\mathrm{CO}_{2}$ Flooding: mechanisms, limitations, and main problems

\subsubsection{Miscible $\mathrm{CO}_{2}$ flooding: emerging trends}

According to a recent and comprehensive literature review on the history and development of $\mathrm{CO}_{2}$ mobility control and profile modification technologies prepared by Enick \& Olsen (2012) for the U.S.A. National Energy Technology Laboratory (NETL), the emerging trends in $\mathrm{CO}_{2}$ flooding include the following: increasing $\mathrm{CO}_{2}$ injection volumes by $50 \%$ or more, horizontal wells for injection or production, improving mobility ratio and flood conformance, extending the conditions under which miscibility between the oil and $\mathrm{CO}_{2}$ can be achieved, innovative flood design and well placement, and the application of advanced methods for monitoring flood performance. However, the short term emphasis of the emerging technologies will be on the development and 
identification of techniques that allow to overcome the most urgent $\mathrm{CO}_{2}$ miscible process limitations and operational problems such as poor sweep eficiency, unfavorable injectivity profiles, gravity override, high ratios of $\mathrm{CO}_{2}$ to oil produced, early breakthrough, and viscous fingering. Thus it is necessary to identify effective and affordable $\mathrm{CO}_{2}$ thickeners that would allow increase the viscosity of $\mathrm{CO}_{2}$ in a carefully controlled manner simply by changing the thickener concentrations. Ideally, the $\mathrm{CO}_{2}$-soluble thickener would be brineand crude oil-insoluble, which would inhibit its partitioning into these other fluid phases and its adsorption onto the reservoir rock. Other technologies that will be carefully looked at are the effective design of $\mathrm{CO}_{2}$ foams for mobility reduction, nanoparticle-stabilized foams, the alternating or simultaneous injection of aqueous nano-silica dispersions and $\mathrm{CO}_{2}$, especially for high temperature reservoirs where chemical degradation of surfactants might be a concern.

\subsubsection{Thermal recovery processes}

Thermal recovery processes use thermal energy in some form both to increase the reservoir temperature and therefore to decrease the viscosity of the oil, which makes possible the displacement of oil towards the producing wells. Thermal recovery processes are globally the most advanced EOR processes, which are classified in three main techniques as follows (Green \& Willhite, 1998).

- $\quad$ Steam Drive

- Cyclic Steam Injection

- In-situ Combustion or Fire flooding

\subsubsection{Steam drive}

Steam drive, also known as steam injection or continuous steam injection, involves generating steam of about $80 \%$ quality on the surface and forcing this steam down the injection wells and into the reservoir. When the steam enters the reservoir, it heats up the oil and reduces its viscosity. As the steam flows through the reservoir, it cools down and condenses. The heat from the steam and hot water vaporizes lighter hydrocarbons, or turn them into gases. These gases move ahead of the steam, cool down, and condense back into liquids that dissolve in the oil. In this way, the gases and steam provide additional gas drive. The hot water also moves the thinned oil to production wells, where oil and water are produced (Van Dyke, 1997).

\subsubsection{Cyclic steam injection}

Cyclic steam injection is also termed huff and puff; this operation involves only one well that functions either as injection and production well. In this process steam is injected into the reservoir for several days or weeks to heat up the oil. Then, steam injection is stopped and the well is shut in to allow the reservoir soak for several days. In the reservoir, the steam condenses, and a zone of hot water and less viscous oil forms. Later on, the well is brought into production and the hot water and thinned oil flow out. This cyclic process of steam injection, soaking, and production can be repeated until oil recovery stops (Van Dyke, 1997). Figure 15 summarizes the mechanisms, limitations, and problems encountered during steam drive and cyclic steam injection. 


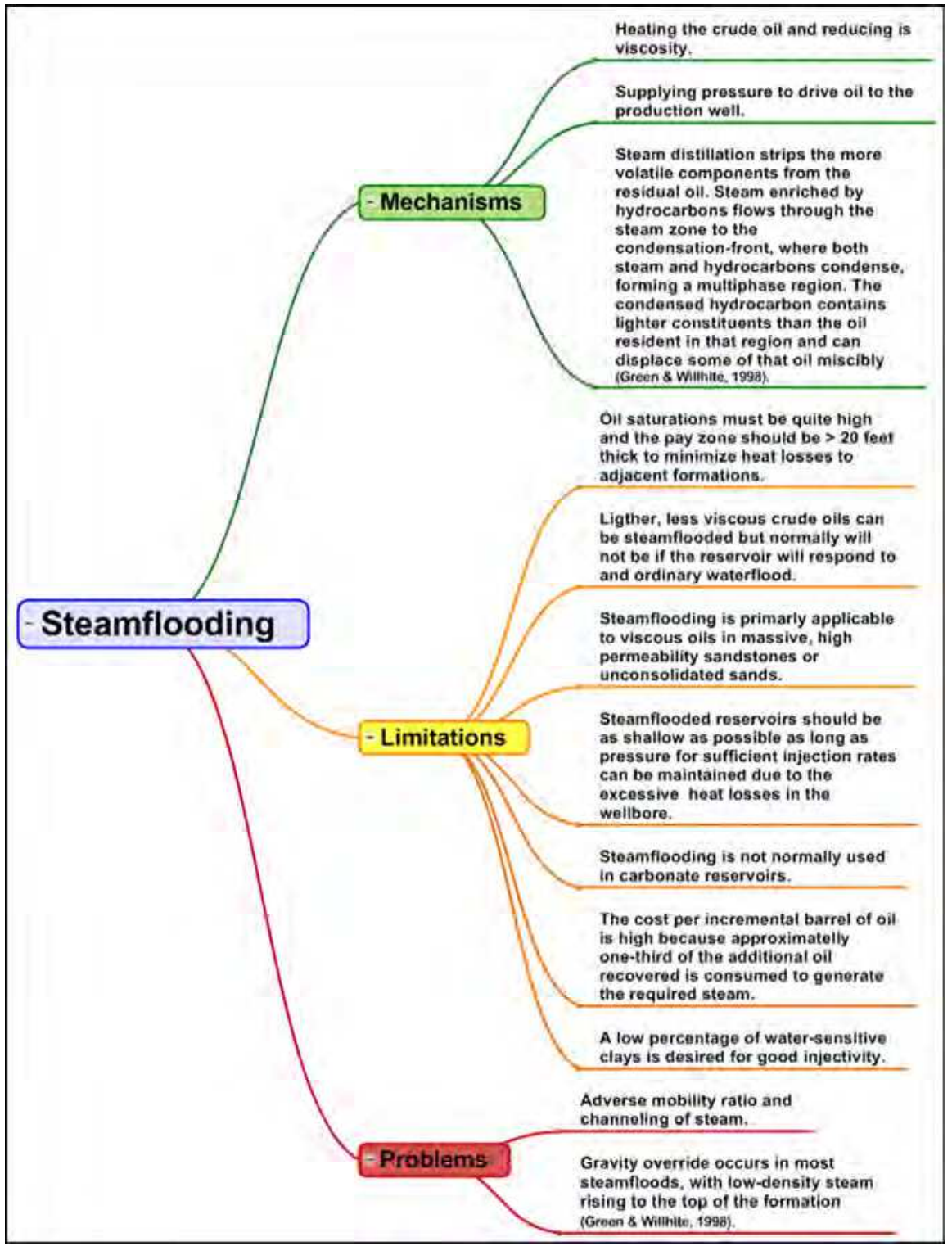

Fig. 15. Steamflooding: mechanisms, limitations, and problems (Adapted from Lyons \& Plisga, 2005).

\subsubsection{In-situ combustion}

In-situ combustion or fire flooding is a process in which an oxygen containing gas is injected into a reservoir where it reacts with the oil contained within the pore space to create a hightemperature self-sustaining combustion front that is propagated through the reservoir. 
Ignition may be induced through electrical or gas igniters of may be spontaneous if the crude oil has sufficient reactivity. In most cases the injected gas is air and the fuel consumed by the combustion is a residuum produced by a complex process of cracking, coking, and steam distillation that occurs ahead of the combustion front. The heat from the combustion thins out the oil around it, causes gas to vaporize from it, and vaporizes the water in the reservoir to steam. Steam, hot water, and gas all act to drive oil in front of the fire to production wells. In-situ combustion is possible if the crude-oil/rock combination produces enough fuel to sustain the combustion front. In-situ combustion field tests have been carried out in reservoir containing API gravities from 9 to 40API (Green \& Willhite, 1998; Van Dyke, 1997). The mechanisms, limitations, and problems occurring during in-situ combustion applications are briefly presented in Figure 16.

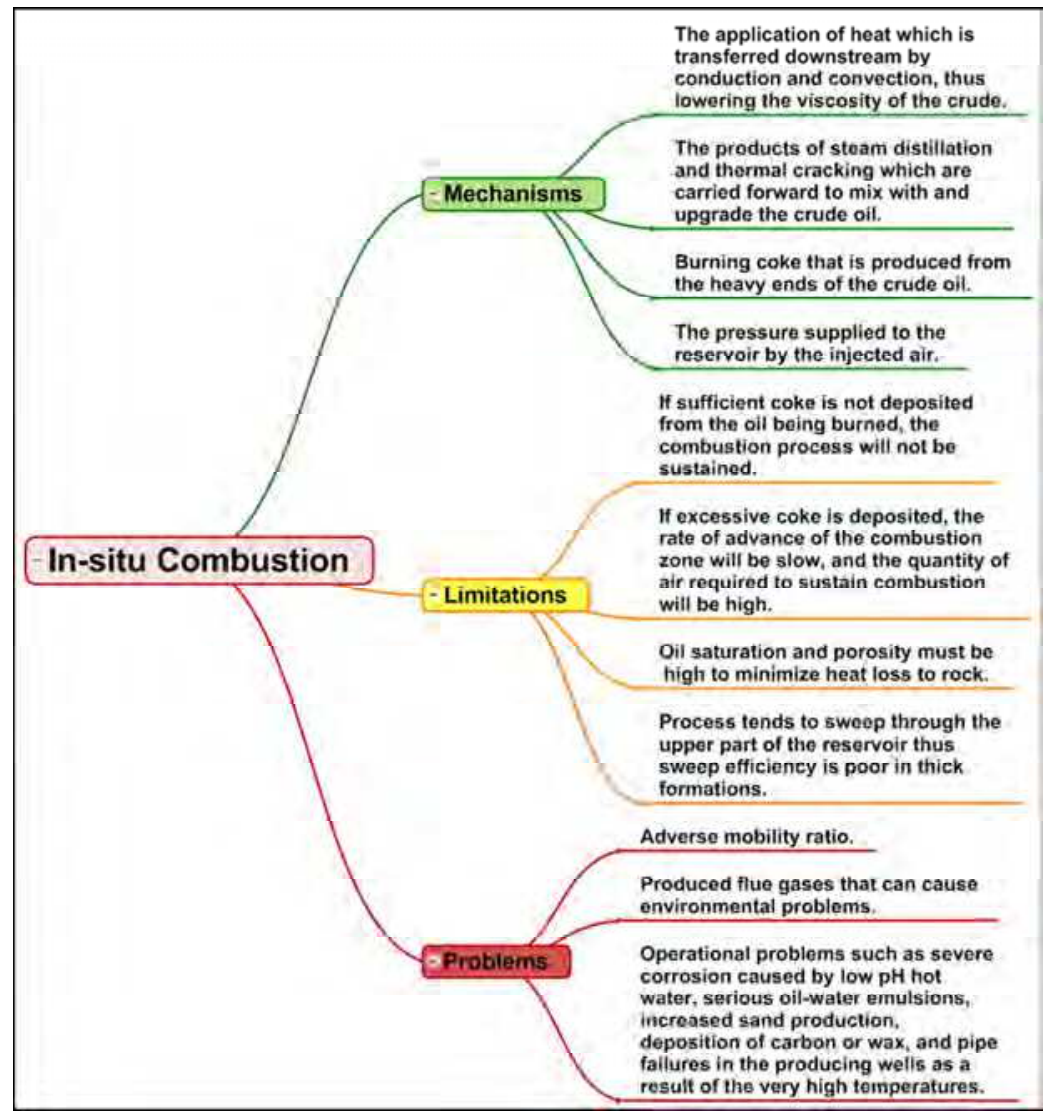

Fig. 16. In-situ Combustion: mechanisms, limitations, and problems (Adapted from Lyons \& Plisga, 2005).

As previously indicated, thermal recovery processes are the most advanced EOR processes and contribute significant amounts of oil to daily production. Most thermal oil production is the result of cyclic steam and steamdrive. New thermal processes have derived from 
steamflooding and in-situ combustion, however several of these newly proposed methods at early stages of evaluation and are not expected to have an impact on oil production in the near future (Green \& Willhite, 1998; Manrique et al., 2010). Figure 17 outlines several of the recent advances in thermal oil recovery processes (AOSC, 2008; OSDG, 2009; Shah et al., 2009, 2010; Meridian, 2006).

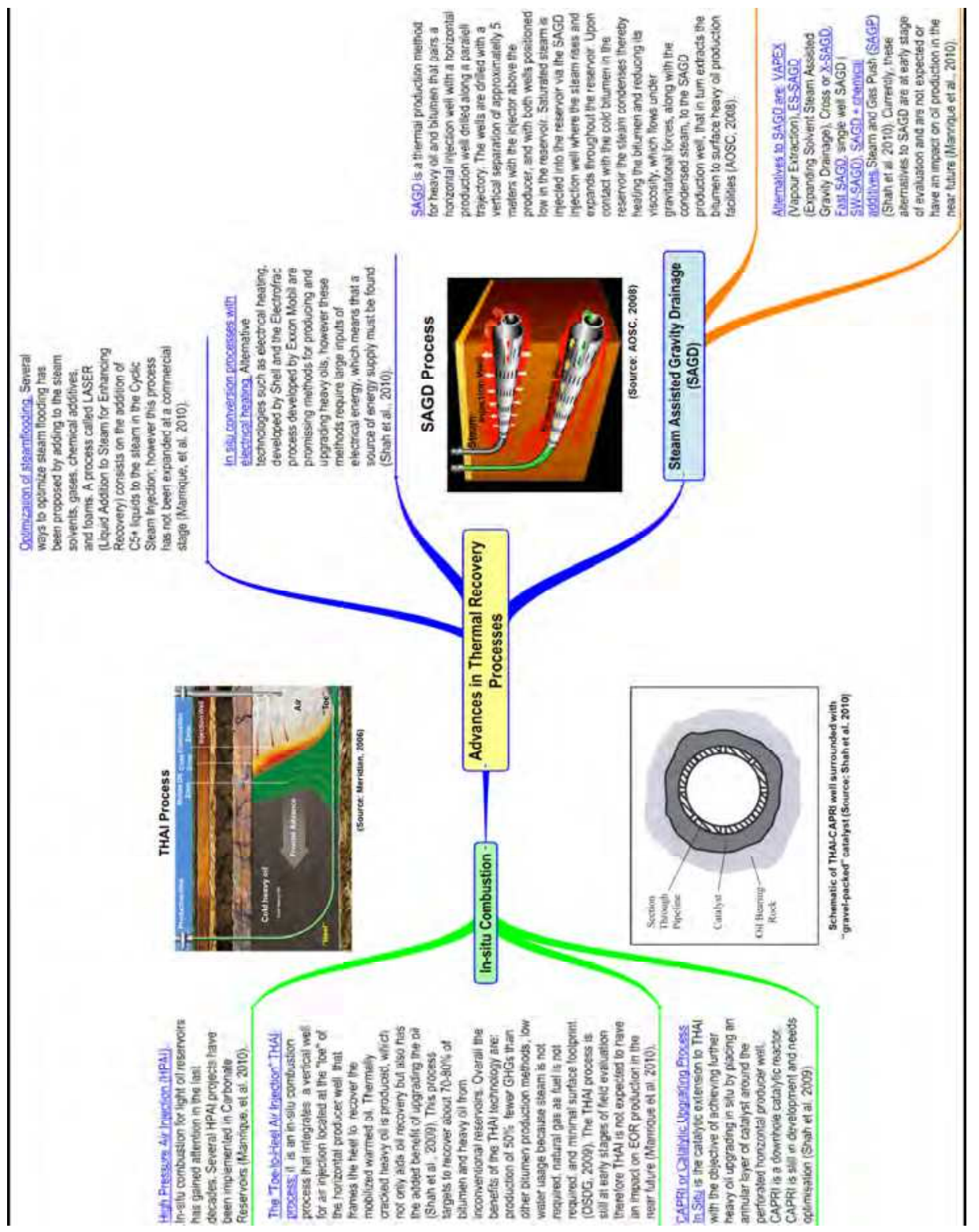

Fig. 17. Advances in Thermal Oil Recovery 
As reported in a comprehensive review of EOR projects prepared by Manrique et al., (2010), thermal EOR projects have been concentrated mostly in Canada, the Former Sovietic Union, U.S.A., and Venezuela. Several EOR thermal projects have been also reported in Brazil and China but in a lesser extend. For the specific case of bitumen production, it is expected that the SAGD process will continue to expand for the production of bitumen from the Alberta's oil sands. Numerous thermal oil recovery projects are reported in the literature; for instance Manrique et al. (2010) presents several examples of recent thermal projects conducted worldwide.

\subsubsection{Other EOR processes}

Other important EOR processes include foam flooding and microbial enhanced oil recovery (MEOR), among others.

\subsubsection{Foam flooding}

Foam is a metastable dispersion of a relatively large volume of gas in a continuous liquid phase that constitutes a relatively small volume of the foam. The gas content in classical foam is quite high (often 60 to $97 \mathrm{vol} \%$ ). Bulk foams are formed when gas contacts a liquid containing a surfactant in the presence of mechanical agitation (Sydansk \& RomeroZerón, 2011).

In oilfield applications, the use of $\mathrm{CO}_{2}$ foams has been considered a promissing technique for $\mathrm{CO}_{2}$ mobility control (Enick \& Olsen, 2012) and steamflooding mobility control (Hirasaki et al., 2011). The use of foams for mobility control in surfactant flooding, specifically at high temperatures (due to polymer degradation), in alkaline-surfactant flooding, surfactant/polymer projects, and in alkaline/surfactant/polymer flooding have been reported (Hirasaki et al., 2011).

The reduced mobility of $\mathrm{CO}_{2}$ foams in porous media is attributed to the flow of dispersed high-pressure $\mathrm{CO}_{2}$ droplets separated by surfactant-stabilized lamellae within the porous of the formation (Enick \& Olsen, 2012). The largest pores are occupied by cells/droplets of the non-wetting $\mathrm{CO}_{2}$ phase, which enables the gas to be transported through the pores along with the lamellae that separate them. These "trains" of flowing $\mathrm{CO}_{2}$ bubbles encounter drag forces related to the pore surfaces and constrictions that lead to alteration of the gas-liquid interface by viscous and capillary forces. Further, the transport of surfactant from the front to the rear of moving bubbles establishes a surface-tension gradient that impedes bubble flow. These phenomena give the flowing foam a nonNewtonian character and an apparently high viscosity, or low mobility, compared to pure $\mathrm{CO}_{2}$ and water flowing through the pores in the absence of surfactant and lamellae (Tang \& Kovscek, 2004, as cited in Enick \& Olsen, 2012). The intermediate size pores can become filled with immobile, trapped bubbles of the gas phase, which reduces the pore volume available for the flow of $\mathrm{CO}_{2}$ foam through the rock. The majority of the gas within foam in sandstone at steady state can be trapped in these intermediate size pores (Chen et al., 2008, as cited in Enick \& Olsen, 2012). The gas trapping leads to gas blocking which, in turn, reduces the gas mobility even further (Enick \& Olsen, 2012). In oilfield operations, foams can be applied as a viscosity-enhancement agent or as a permeability-reducing treatment (Sydansk \& Romero-Zerón, 2011). 
- A mobility control foam is one in which the mobility of the foam is reduced approximately to a level that is comparable to the oil being displaced in an attempt to supress fingering and channeling. Typically aternated slugs of surfactant solution and $\mathrm{CO}_{2}$ are injected into the reservoir. Once the foam is formed, it is intended to propagate throughout the formation as an in-depth mobility control to improve sweep efficiency through the $\mathrm{CO}_{2}$ flood (Enick \& Olsen, 2012).

- Conformance control foam is intended to selectively generate strong, very low mobility foams in highly permeable, watered-out thief zones. These foams are also referred to as blocking/diverting foams, or injection profile improvement foams. This is achieved by employing higher concentrations of surfactant in the aqueous solution that is injected alternately with $\mathrm{CO}_{2}$ (Enick \& Olsen, 2012).

Although, there are numerous reports on oilfield application of foams and their performace (Enick \& Olsen, 2012; and Marinque et al. 2011); foams for conformance improvement to date have not been applied widely in a succesful, commercially atractive, and profitable manner; on the contrary the application of foams is considered to be an advanced and nonroutine conformance-improvement technology (Pope, 2011; Sydansk \& Romero-Zerón 2011). Nonetheless, with the further development of technlogies such is the case of new surfactants for $\mathrm{CO}_{2}$ and nanoparticles as foam stabilizers, the oilfield application of foams might be revitalized (Pope, 2011; Sydansk \& Romero-Zerón, 2011).

\subsubsection{Microbial Enhanced Oil Recovery (MEOR)}

Microbial Enhanced Oil Recovery (MEOR) relies on microbes to ferment hydrocarbons and produce by-products such as biosurfactants and carbon dioxide that help to displace oil in a similar way than in conventional EOR processes. Bacterial growth occurs at exponential rates, therefore biosurfactants are rapidly produced. The activity of biosurfactants compare favourably with the activity of chemically synthesized surfactants. The injection of nutrients such as sugars, nitrates or phosphates stimulates the growth of the microbes and aid their performance. MEOR applications are limited to moderate reservoir temperatures, because high temperatures limit microbial life and the availability of suitable nutrients (Shah et al., 2010). In the 1980's, researches and industry focused considerable efforts toward EOR processes including MEOR, which has always been an attractive EOR method due to its low cost and potential to improve oil recovery efficiencies (Aladasani \& Bai, 2010). At present, researchears are still evaluating and advancing MEOR processes (Soudmand-asli, et al., 2007). For instance, a chemical flooding simulator the "UTCHEM" developed at the University of Texas at Austin by Delshad et al., (2002) has recently incorporated a model that is capable of qualitatively mimic the oil recovery mechanisms occuring during MEOR processes. Presently, few commercial MEOR operators continue to offer customized microbial process applications.

MEOR oilfield applications have shown mixed results. On average, MEOR field trials results have been poor and published studies offer little insights into the potential field viability of MEOR. The main reason is that the current state of knowledge of bioreaction kinetics such as nutrient reaction kinetics, selectivity, and level of conversion are still lacking. For instance, microbial gas production, $\mathrm{CO}_{2}$ and $\mathrm{CH}_{4}$, are commoly cited as contributing to oil recovery, however is unlikely that these gases could be produced in-situ in the quantities needed for effective oil displacement. Similarly, the in-situ generation of viscosifying agents is intrinsically unstable, which indicates that ex-situ polymer injection should be required 
for mobility control of MEOR (Bryant \& Lockhart, 2002). Therefore, MEOR is potentially a "high risk, high reward" process as concluded by Bryant \& Lockhart, (2002) in "Reservoir Engineering Analysis of Microbial Enhanced Oil Recovery"; in which the reward refers to the fact that the difficulty and the logistical costs of implementing the process would approach those of implementing a waterflood rather than an EOR process. The risk is associated with the many and severe performance constraints that a microbial system would have to satisfy to take advantage of an in-situ carbon source. Therefore MEOR feasibility still requires considerable research and development.

Conversely, published information of MEOR oilfield applications have demonstrated the benefits of MEOR as is the case of the application of microbial enhanced oil recovery technique in the Daqing Oilfield reported by Li et al., (2002), which claims and incremental oil recovery by $11.2 \%$ and a reduction of oil viscosity of $38.5 \%$ in the pilot tests. Another report by Portwood J. T. (1995), presented the analysis of the effectiveness and economics of 322 MEOR projects carried out in more than 2,000 producing oil wells in the United States that applied the same single MEOR technology. This analysis indicated that the MEOR process applied effectively mobilized residual crude oil. $78 \%$ of the MEOR projects demonstrated on average $36 \%$ of incremental oil production. The MEOR process implemented worked effectively under reservoir conditions and is environmentally friendly. Common operational problems associated with paraffin, emulsion, scale, and corrosion were significantly reduced and oil production decrease was not observed during the MEOR projects time frame. This MEOR technology demonstrated to be economically and technologically feasible. The producers average return on investment from MEOR was 5:1 within the first 24 months of MEOR and the average time to project payback was six months. In Chapter 3, a more detailed review of the MEOR process is presented.

\subsubsection{EOR processes and technical maturity}

According to Regtien (2010), mature EOR processes that are well established and therefore can be implemented without significant adaptations are: vertical well steam drive, cyclic steam stimulation, miscible gas injection, and polymer flooding, as shown in Figure 18. The second group of EOR processes in the middle of the curve (Fig. 18) presents the technologies that require a significant amount of optimization and field trials to de-risk the concept or get the correct full field design. These EOR processes are alkaline-surfactant-polymer (ASP) flooding, in-situ combustion such as High Pressure Air Injection (HPAI), steam assisted gravity drainage (SAGD), low-salinity waterflooding, and high pressure steam injection. The EOR technologies at the bottom-left of the curve (Fig. 18) outlines processes that are relatively immature but very promising that still require extensive research and development. These processes are in-situ upgrading, foams, and hybrid processes (Regtien, 2010).

\subsubsection{Selection of EOR processes}

According to Pope (2011) the selection of a suitable EOR process for a specific oil formation requires and integrated study of the reservoir and its characteristics. Some basic questions that the operator must address during the decision making process, rather than follow conventional wisdom or simplified screening criteria that may be out of date are outlined in Figure 19. 


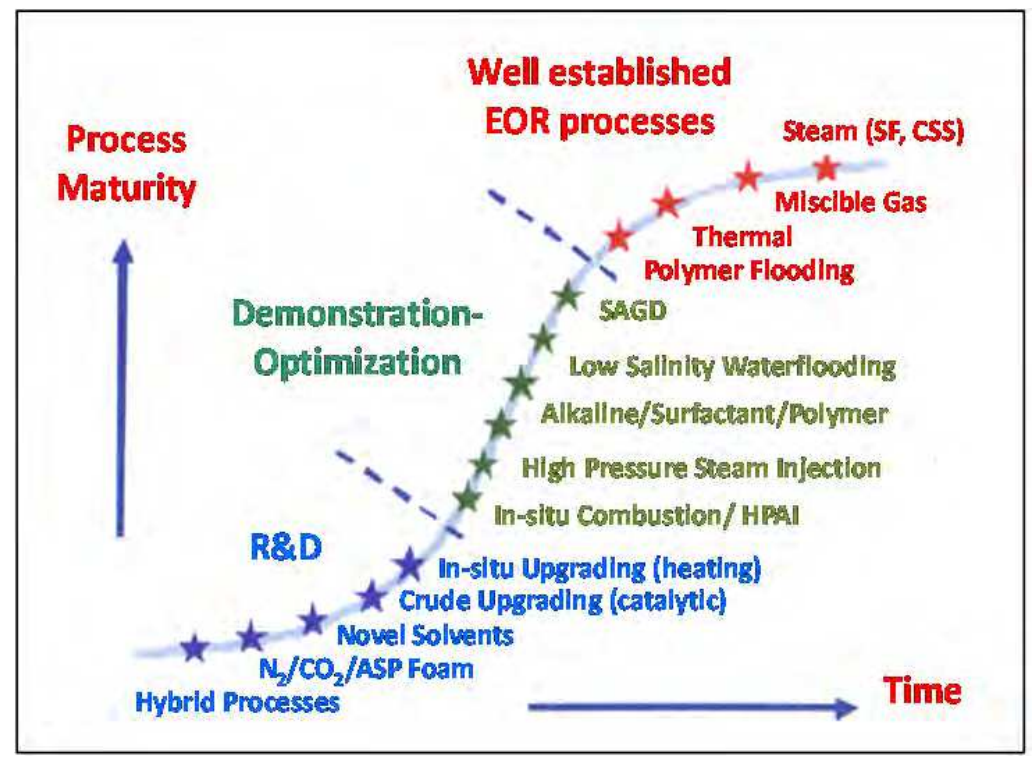

Fig. 18. Maturation Curve for Enhanced Oil Recovery (Adapted from Regtien, 2010).

As Pope (2011) continues...once these questions are carefully addresed based on sound technical analysis the ideal strategy is to use both simplified models and detailed reservoir simulation models to evaluate the options assuming the process might be economic. If initial calculations indicate the process may be profitable, then there will be a need for additional laboratory and field measurements followed by more modeling. In many cases, a single well test will be justified to evaluate injectivity, reduction in oil saturation, and other performance indicators that can only be assessed with field tests. When comparing the economics of different processes, many factors must also be taken into account. Chemical methods have the advantage of lower capital costs than miscible gas and thermal methods, and commercial projects can start small and be expanded if successful without the need for expensive infrastructure such as pipelines (Pope, 2011).

Detailed outlines of EOR screening criteria are available in the literature that are based on matching particular EOR processes to reservoir properties such as ${ }^{\circ} \mathrm{API}$ gravity, reservoir depth, oil saturation, rock permeability and porosity distribution, oil viscosity distribution, type of rock formation, and reservoir temperature distribution, among others. Aladasani \& Bai, (2010) recently published an updated paper on EOR screening criteria. Practical information on EOR field planning and development strategies are provided by Alvarado and Manrique (2010). A comprehensive screening criteria for EOR based on oilfield data obtained from successful EOR projects worldwide and on oil recovery mechanisms was proposed by Taber et al., (1997a, 1997b). 


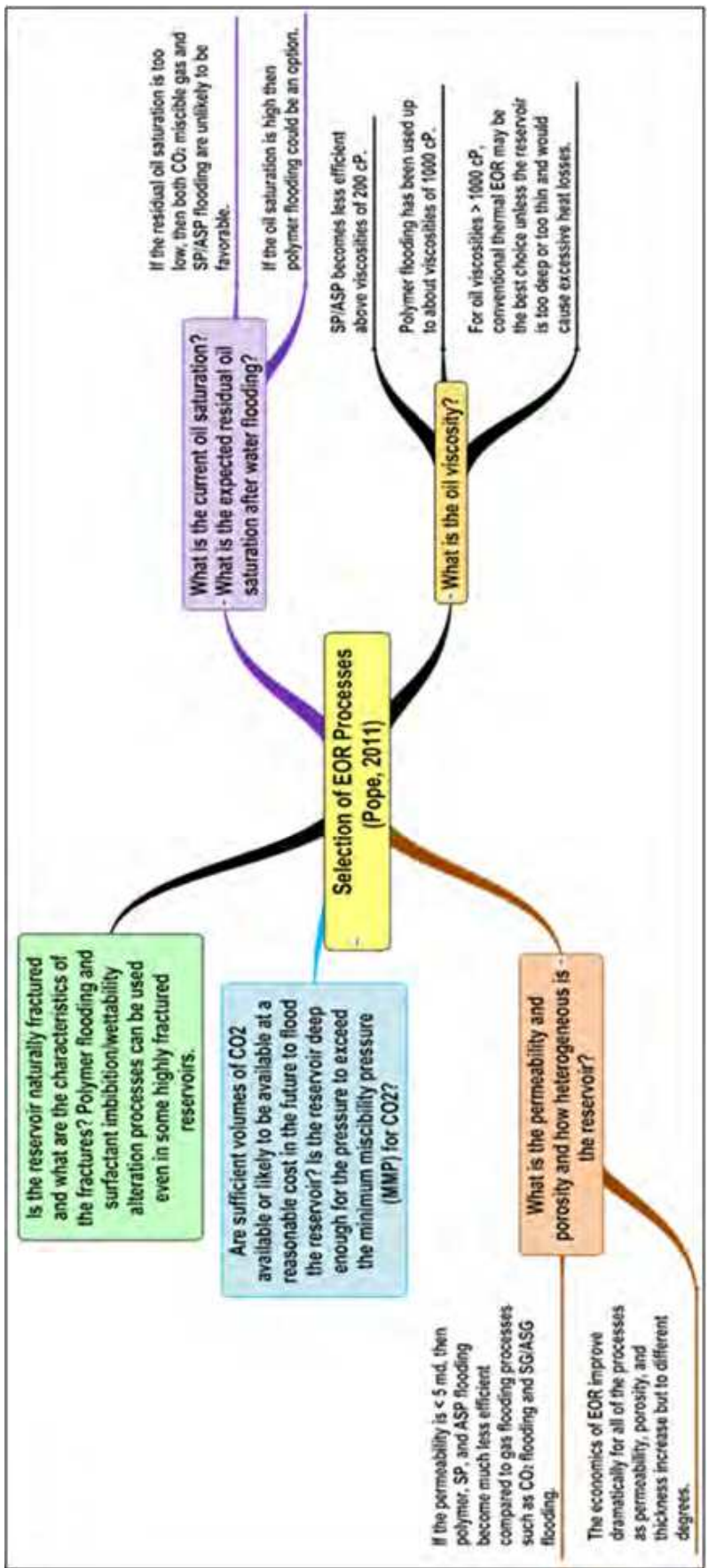

Fig. 19. Selection of EOR Processes: basic questions (Source: Pope, 2011). 
Lately, publications have been focused on reservoir selection for anthropogenic $\mathrm{CO}_{2}$ sequestration and $\mathrm{CO}_{2}$-flood EOR. $\mathrm{CO}_{2}$ sequestration in oil reservoirs is not a straightforward application of existing oil field technology and operating practices (Kovscek 2002). The key issue in this process is to maximize the volume of $\mathrm{CO}_{2}$ that can be retained in a reservoir by physical trapping or by maximizing the $\mathrm{CO}_{2}$ solubility in the reservoir fluids (Aladasani \& Bai, 2010). For instance, Shaw \& Bachu, (2002) developed a method for the rapid screening and ranking of oil reservoirs suited for $\mathrm{CO}_{2}$-flood EOR that is useful for preliminary analyses and ranking of large number of oil pools. To determine reservoir suitability for $\mathrm{CO}_{2}$ flooding, oil reservoirs are screened on the basis of oil gravity, reservoir temperature and pressure, minimum miscibility pressure and remaining oil saturation. Kovscek (2002) proposed screening criteria for $\mathrm{CO}_{2}$ storage and in a subsequent paper Kovscek \& Cakici (2005) reported strategies to cooptimize oil recovery and $\mathrm{CO}_{2}$ storage via compositional reservoir simulation. This study proposed a form of production well control that limits the fraction of gas relative to oil produced as an effective practice for the cooptimization of $\mathrm{CO}_{2}$ sequestration and oil recovery.

\section{Summary}

The current renewed interest on research and development of EOR processes and their oilfield implementation would allow targeting significant volumes of oil accumulations that have been left behind in mature reservoirs after primary and secondary oil recovery operations. The potential for EOR is real and achivable. However, improvements of the operational performance and the economical optimization of EOR projects in the future would require the application of a synergistic approach among EOR processes, improved reservoir characterization, formation evaluation, reservoir modeling and simulation, reservoir management, well technology, new and advanced surveillance methods, production methods, and surface facilities as stated by Pope (2011). This synergistic approach is in line with the Smart Fields Concept, also known as Intelligent Field, Digital Field, i-Field or e-Field, developed by Shell International Exploration and Production that involves an integrated approach, which consists of data acquisition, modeling, integrated decision making, and operational field management, each with a high level of integration and automation (Regtien, 2010).

\section{References}

Adkins S., Liyanage P., Pinnawala Arachchilage G., Mudiyanselage T., Weerasooriya U. \& Pope, G. "A New Process for Manufacturing and Stabilizing High-Performance EOR Surfactants at Low Cost for High-Temperature, High-Salinity Oil Reservoirs." SPE Paper 129923 presented at the 2010 SPE Improved Oil Recovery Symposium. Tulsa, Oklahoma, U.S.A., 24-28 April: Society of Petroleum Engineers, 2010. 1-9.

Ahmed T. \& McKinney P. Advanced Reservoir Engineering. Burlington, MA: Elsevier, 2005.

Aladasani A. \& Bai B. "Recent Developments and Updated Screening Criteria of Enhanced Oil Recovery Techniques." SPE 130726 presented at the CPS/SPE International Oil \& Gas Conference and Exhibition. Beijing, China, 8-10 June: Society of Petroleum Engineers, 2010. 1-24. 
Al-Assi A. A., Willhite G. P., Green D. W. \& McCool C. S. "Formation and Propagation of Gel Agregates Using Partially Hydrolyzed Polyacrylamide and Aluminun Citrate." SPE Paper 100049 presented at the 2006 SPE/DOE Symposium on Improved Oil Recovery. Tulsa, Oklahoma, U.S.A., 22-26 April: Society of Petroleum Engineers, 2006. 1-13.

Alvarado V. \& Manrique E. Enhanced Oil Recovery: Field Planning and Development Strategies. Burlington, MA, USA.: Gulf Professional Publishing, 2010.

AOSC -Athabasca Oil Sands Corporation. Technology. Steam Assisted Gravity Drainage (SAGD) vs. Mining. 2008.

http://www.aosc.com/corporate-overview/technology.html (accessed April 5, 2012).

Azira H., Tazerouti A. \& Canselier J. P. "Phase Behaviour of Pseudoternary Brine/Alkane/Alcohol-secondary Alkanesulfonates Systems. Surfactant ratio effects of salinity and alcohol." Journal of Thermal Analysis and Calorimetry, 92 (3), 2008: 759-763.

Bai, B., Shuler P., Qu Q. \& Wu Y. Preformed Particle Gel For Conformance Control. Progress Report. RPSEA Subcontract \# 07123-2, Missouri: Missouri University of Science and Technology (MS \& T), 2009.

Banat I. M., Makkar R. S. \& Cameotra S. S. "Potential commercial applications of microbial surfactants." Appl Microbiol Biotechnol, 53, 2000: 495-508.

Barnes J., Dirkzwager H., Smit J.R., Smit J. P., On A., Navarrete R. C., Ellison B. H., Buijse M. A. \& Rijswijk B. V. "Application of Internal Olefin Sulfonates and Other Surfactants to EOR. Part 1: Structure-Performance Relationships for Selection at Different Reservoir Conditions." SPE Paper 129766 presented at the 2010 SPE Improved Oil Recovery Symposium. Tulsa, Oklahoma, U.S.A., 24-28 April: Society of Petroleum Engineers, 2010. 1-16.

Berger P. D. \& Lee H. C. "New Anionic Alkylaryl Surfactants Based on Olefin Sulfonic Acids." Journal of Surfactants and Detergents, 5 (1) January, 2002: 39-43.

Bou-Mikael S., Asmadi F., Marwoto D. \& Cease C. "Minas Surfactant Field Trial Tests Two Newly Designed Surfactants with High EOR Potential." SPE Paper 64288 presented at the SPE Asia Pacific Oil and Gas Conference and Exhibition. Brisbane, Australia October: Society of Petroleum Engineers Inc., 2000. 1-12.

Bryant S. \& Lockhart T. "Reservoir Engineering Analysis of Microbial Enhanced Oil Recovery." SPE Reservoir Evaluation \& Engineering, 5 (5), 2002: 365-374.

Buijse M. A., Prelicz R. M., Barnes J. R. \& Cosmo C. "Application of Internal Olefin Sulfonates and Other Surfactants to EOR. Part 2: The Design and Execution of an ASP Field Test." SPE Paper 129769 presented at the 2010 SPE Improved Oil Recovery Symposium. Tulsa, Oklahoma, U.S.A., 24-28 April: Society of Petroleum Engineers, 2010. 1-12.

Cao Y. \& Li H. "Interfacial activity of a novel family of polymeric surfactants." European Polymer Journal 38, 2002: 1457-1463.

Chang H., Sui X., Xiao L., Liu H., Guo S., Yao Y., Xiao Y., Chen G., Song K. \& Mack J. C. "Successful Field Pilot of In-Depth Colloidad Dispersion Gel (CDG) Technology in Daqing Oil Field." SPE Paper 89460 presented at the 2004 SPE/DOE Fourteenth Symposium on Improved Oil Recovery. Tulsa, Oklahoma, U.S.A., 17-21 April: Society of Petroleum Engineers Inc., 2004. 1-15. 
Choi, S. K. A Study of a $\mathrm{pH}$-sensitive Polymer for Novel Conformance Control Applications. Master Science Thesis, Austin, Texas: The University of Texas , 2005.

Choi S. K., Ermel Y. M., Bryant S. L., Huh C. \& Sharma M. M. "Transport of a pH-Sensitive Polymer in Porous Media for Novel Mobility-Control Applications." SPE Paper 99656 presented $a$ the 2006 SPE/DOE Symposium on Improved Oil Recovery. Tulsa, Oklahoma, U.S.A., 22-26 April 2006: Society of Petroleum Engineers Inc., 2006. 1-15.

Chung T., Bae W., Nguyen N. T. B., Dang C. T. Q., Lee W. \& Jung B. "A Review of Polymer Conformance Treatment: A Successful Guideline for Water Control in Mature Fields." Energy Sources, Part A: Recovery, Utilization, and Environmental Effects 34(2), 2011: 122-133.

Coste J. P., Liu Y., Bai B., Li Y., Shen P., Wang Z. \& Zhu G. "In-Depth Fluid Diversion by PreGelled Particles. Laboratory Study and Pilot Testing." SPE Paper 59362 presented at the 2000 SPE/DOE Improved Oil Recovery Symposium. Tulsa, Oklahoma, 3-5 April: Society of Petroleum Engineers Inc., 2000. 1-8.

Craft B. C. \& Hawkins, M. F. Applied Petroleum Reservoir Engineering (Second Edition). New Yersey, ISBN0-13-039884-5: Prentice Hall PTR, 1991.

Cui X., Li Z., Cao X., Song X. \& Zhang X. "A Novel PPG Enhanced Surfactant-Polymer System for EOR." SPE Paper 143506 presented at the 2011 SPE Enhanced Oil Recovery Conference. Kuaka Lumpur, Malaysia, 19-21 July: Society of Petroleum Engineers, 2011. 1-8.

Dake L. (1978). Fundamentals of Reservoir Engineering. Elsevier Inc. 0-444-41830-X, San Diego, CA, 1978.

Delshad M., Asakawa K., Pope G. \& Sepehrnoori K. "Simulations of Chemical and Microbial Enhanced Oil Recovery Methods." SPE Paper 75237 presented at the SPE/DOE Improved Oil Recovery Symposium. Tulsa, Oklahoma, 13-17 April: Society of Petroleum Engineers Inc., 2002. 1-13.

Diaz D., Somaruga C., Norman C. \& Romero J. "Colloidal Dispersion Gels Improve Oil Recovery in a Heterogeneous Argentina Waterflood." SPE Paper 113320 presented at the 2008 SPE/DOE Improved Oil Recovery Symposium. Tulsa, Oklahoma, U.S.A. 19-23 April: Society of Petroleum Engineers, 2008. 1-10.

Dupuis G., Rousseau D., Tabary R. \& Grassl B. "How to get the Best Out of Hydrophobically Associative Polymers for IOR? New Experimental Insights." SPE paper 129884 presented at the 2010 SPE Improved Oil Recovery Symposium. Tulsa, 24-28 April: Society of Petroleum Engineers, 2010. 1-12.

Dupuis G., Rousseau D., Tabary R., \& Grassl B. "Injectivity of Hydrophobically Modified Water Soluble Polymers for IOR: Controlled Resistance Factors vs. Flow-Induced Gelation." SPE Paper 140779 presented at the 2011 SPE International Symposium on Oilfield Chemistry. The Woodlands, Texas, U.S.A. 11-13 April: Society of Petroleum Engineers, 2011. 1-13.

Elraies K. A., Tan I. M., Awang M. \& Saaid I. "The Synthesis and Performance of Sodium Methyl Ester Sulfonate for Enhanced Oil Recovery." Petroleum Science and Technology, 28(17), 2010: 1799-1806.

Enick R. \& Olsen, D. Mobility and Conformance Control for Carbon Dioxide Enhanced Oil Recovery $\left(\mathrm{CO}_{2}\right.$-EOR) via Thickeners, Foams, and Gels-A Detailed Literature Review of 40 Years of Research. Contract DE-FE0004003. Activity 4003.200.01, Pittsburgh: National Energy Technology Laboratory (NETL), 2012. 
Feitler D. The Herculean Surfactant for Enhanced Oil Recovery, Request \#60243. Cleveland, April 17, 2009.

Fielding Jr. R. C., Gibbons D. H. \& Legrand F. P. "In-Depth Drive Fluid Diversion Using an Evolution of Colloidal Dispersion Gels and New Bulk Gels: An operational Case History of North Rainbow Ranch Unit." SPE/DOE Paper 27773 presented at the 1994 SPE/DOE Ninth Symposium on Improved Oil Recovery. Tulsa, Oklahoma, U.S.A., 1720 April: Society of Petroleum Engineers, Inc., 1994. 1-12.

Flaaten A. K., Nguyen Q. P., Pope G. \& Zhang J. "A Systematic Laboratory Approach to Low-Cost, High-Performance Chemical Flooding." SPE Paper 113469 presented at the 2008 SPE/DOE Improved Oil Recovery Symposium. Tulsa, Oklahoma, U.S.A. 19-23 April: Society of Petroleum Engineers, 2008. 1-20.

Frampton H., Morgan J. C., Cheung S. K., Munson L., Chang K. T. \& Williams D. "Development of a novel waterflood conformance control system." SPE Paper 89391 presented at the 2004 SPE/DOE Fourteenth Symposium on Improved Oil Recovery. Tulsa, Oklahoma, U.S.A., 17-21 April: Society of Petroleum Engineers Inc., 2004. 1-9.

Garmeh R., Izadi M., Salehi M., Romero J. L., Thomas C. P. \& Manrique, E. J. "Thermally Active Polymer to Improve Sweep Efficiency of Water floods: Simulation and Pilot Design Approaches." SPE Paper 144234 presented at the 2011 SPE Enhanced Oil Recovery Conference. Kuala Lumpur, Malaysia, 19-21 July: Society of Petroleum Engineers, 2011. 1-15.

Green D. W. \& Willhite G. P. Enhanced Oil Recovery. Richardson, Texas: Society of Petroleum Engineers, 1998.

Hirasaki G. J., Miller C. A., \& Puerto M. "Recent Advances in Surfactant EOR." SPE Journal, 16 (4), 2011: 889-907.

Huh C., Choi S. K. \& Sharma M. M. "A Rheological Model for pH-Sensitive Ionic Polymer Solutions for Optimal Mobility-Control Applications." SPE Paper 96914 presented at the 2005 SPE Annual Technical Conference and Exhibition. Dallas, Texas, U.S.A. 9-12 October: Society of Petroleum Engineers Inc., 2005. 1-13.

Iglauer S., Wu Y., Shuler P. J., Blanco M., Tang Y. \& Goddard III W. A. "Alkyl Polyglycoside Surfactants for Improved Oil Recovery." SPE Paper 89472 presented at the 2004 SPE/DOE Fourteenth Symposium on Improved Oil Recovery. Tulsa, Oklahoma, U.S.A. 17-21 April: Society of Petroleum Engineers, 2004. 1-9.

Izgec O. \& Shook, G. M. "Design Considerations of Waterflood Conformance Control with Temperature-Triggered Low Viscosity Sub-micron Polymer." SPE Paper 153898 presented at the 2012 SPE Western Regional Meeting. Bakersfield, California, U.S.A., 19-23 March: Society of Petroleum Engineers, 2012. 1-12.

Jackson A. C. Experimental study of the Benefits of Sodium Carbonate on Surfactants for Enhanced Oil Recovery. Master of Science in Engineering, Austin, Texas: The University of Texas at Austin, 2006.

Kovscek A. R. "Screening Criteria for $\mathrm{CO}_{2}$ Storage in Oil Reservoirs." Petroleum Science and Technology, 20 (7 - 8), 2002: 841-866.

Kovscek A. R. \& Cakici, M.D. "Geological storage of carbon dioxide and enhanced oil recovery. II. Cooptimization of storage and recovery." Energy Conversion and Management, 46 (11-12), July 2005, 1941-1956.

Lake L. W. "Enhanced Oil Recovery." SPE ATCE. Training Courses. Florence, Italy: Society of Petroleum Engineers, September 23, 2010. 
Lake L. W. Enhanced Oil Recovery. Englewood Cliffs, New Jersey: Prentice Hall, 1989.

Lalehrokh, F. \& Bryant, S. L. "Application of pH-Triggered Polymers for Deep Conformance Control in Fractured Reservoirs. "SPE Paper 124773 presented at the 2009 SPE Annual Technical Conference and Exhibition. New Orleans, Louisiana, U.S.A. 4-7 October: Society of Petroleum Engineers Inc., 2009. 1-11.

Levitt D. B. "Experimental Evaluation of High Performance EOR Surfactants for a Dolomite Oil Reservoir." Master of Science in Engineering, Austin: The University of Texas at Austin, 2006.

Levitt D.B., Jackson A. C., Heinson C., Britton L. N., Malik T., Dwarakanath V., \& Pope G. A. "Identification and Evaluation of High-Performance EOR Surfactants." SPE Reservoir Evaluation E Engineering, 12 (2), 2009: 243-253.

Li, Q., Kang C., Wang H., Liu C. \& Zhang C. "Application of microbial enhanced oil recovery technique to Daqing Oilfield." Biochemical Engineering Journal, 11, 2002: 197-199.

Lu, X., Song K., Niu J. \& Chen F. "Performance and Evaluation Methods of Colloidal Dispersion Gels in the Daqing Oil Field." SPE Paper 59466 presented at the 2000 SPE Asia Pacific Conference on Integrated Modelling for Asset Management. Yokohama, Japan, 25-26 April: Society of Petroleum Engineers Inc., 2000. 1-11.

Lyons W. \& Plisga, B. S. (Eds). Standard Handbook of Petroleum \& Natural Gas Engineering (Second edition). Burlington, MA: Elsevier Inc. ISBN-13:978-0-7506-7785-1, 2005.

Manrique E., Thomas C., Ravikiran R., Izadi M., Lantz M., Romero J. \& Alvarado V. "EOR: Current Status and Opportunities." SPE Paper 130113 presented at the 2010 SPE Improved Oil Recovery Symposium. Tulsa, Oklahoma, U. S.A., 24-28 April: Society of Petroleum Engineers, 2010. 1-21.

Meridian. Energy Insights. August 1, 2006.

http://www.safehaven.com/article/5639/energy-insights (accessed April 6, 2012).

Muruaga E., Flores M., Norman C. \& Romero J. "Combining Bulk Gels and Colloidal Dispersion Gels for Improved Volumetric Sweep Efficiency in a Mature Waterflood." SPE Paper 113334 presented at the 2008 SPE/DOE Improved Oil Recovery Symposium. Tulsa, Oklahoma, U.S.A., 19-23 April: Society of Petroleum Engineers, 2008. 1-12.

Mustoni J. L., Norman C. A., \& Denyer P. "Deep Conformance Control by a Novel Thermally Activated Particle System to Improve Sweep Efficiency in Mature Waterfloods on the San Jorge Basin." SPE Paper 129732 presented at the 2010 SPE Improved Oil Recovery Symposium. Tulsa, Oklahoma, U.S.A. 24-28 April: Society Petroleum Engineers, 2010. 1-10.

Norman C. A., Smith J. E. \& Thompson, R. S. "Economics of In-Depth Polymer Gel Processes." SPE Paper 55632 presented at the 1999 SPE Rocky Mountain Regional Meeting. Gillette, Wyoming, 15-18 May: Society of Petroleum Engineers Inc., 1999. 1 $-8$.

Norman C., Turner B., Romero J. L., Centeno G. \& Muruaga, E. "A Review of Over 100 Polymer Gel Injection Well Conformance Treatments in Argentina and Venezuela: Design, Field Implementation, and Evaluation." SPE Paper 101781 presented at the First International Oil Conference and Exhibition in Mexico. Cancun, Mexico, 31 August - 2 September: Society of Petroleum Engineers, 2006. 1 -16. 
Ohms, D., McLeod J., Graff C., Frampton H., Morgam J. C., Cheung S., \& Chang, K.T. "Incremental-Oil Success From Waterflood Sweep Improvement in Alaska." SPE Production E Operations, 25 (3), August 2010: 1-8.

Okasha T. \& Al-Shiwaish, A. "Effect of Brine Salinity on Interfacial Tension in Arab-D Carbonate Reservoir, Saudi Arabia." SPE paper 119600 presented at the 2009 SPE Middle East Oil \& Gas Show and Conference. Bahrain, Kingdom of Bahrain: Society of Petroleum Engineers, 2009. 1-9.

Okeke T. \& Lane, R. "Simulation and Economic Screening of Improved Oil Recovery Methods with Emphasis on Injection Profile Control Including Waterflooding, Polymer Flooding and a Thermally Activated Deep Diverting Gel." SPE Paper 153740 presented at the 2012 SPE Western Regional Meeting. Bakersfield, California, U.S.A. 19-23 March: Society of Petroleum Engineers, 2012. 1-14.

OSDG - The Oil Sands Developers Group . Toe-to-Heel Air Injection (THAI). 2009. http://www.oilsandsdevelopers.ca/index.php/oil-sands-technologies/insitu/the-process-2/toe-to-heel-air-injection-thai. (accessed April 6, 2012).

Ovalles C., Bolivar R., Cotte E., Aular W., Carrasquel J. \& Lujano E. "Novel ethoxylated surfactants from low-value refinery feedstocks." Fuel 80 (4), 2001: 575-582.

Pope G. "Recent Developments and Remaining Challenges of Enhanced Oil Recovery." JPT, 2011: 65-68.

Portwood J. T. "A Commercial Microbial Enhanced Oil Recovery Technology: Evaluation of 322 Projects." SPE Paper 29518 presented at the 1995 Production Operations Symposium. Oklahoma City, OK, U.S.A., 2-4 April: Society of Petroleum Engineers, Inc., 1995. 116.

Puerto M., Hirasaki G. J., Miller C. \& Barnes J. R. "Surfactant Systems for EOR in HighTemperature, High-salinity Environments." SPE Paper 129675 presented at the 2010 SPE Improved Oil Recovery Symposium. Tulsa, Oklahoma, U.S.A., 24-28 April: Society of Petroleum Engineers, 2010. 1-20.

Ranganathan R., Lewis R., McCool C. S., Green D. W. \& Willhite G. P. "Experimental Study of the Gelation Behavior of a Polyacrylamide/Aluminum Citrate ColloidalDispersion Gel System." SPE Journal, 3 (4), December 1998: 337-343.

Regtien J. M. M. "Extending The Smart Fields Concept To Enhanced Oil Recovery." SPE Paper 136034 presented at the 2010 SPE Russian Oil \& Gas Technical Conference and Exhibition. Moscow, Russia, 26-28 October: Society of Petroleum Engineers, 2010. 111.

Reichenbach-Klinke R., Langlotz B., Wenzke B., Spindler C. \& Brodt G. "Hydrophobic Associative Copolymer with Favorable Properties for the Application in Polymer Flooding." SPE Paper 141107 presented at the SPE International Symposium on Oilfield Chemistry. The Woodlands, Texas, U.S.A., 11-13 April: Society of Petroleum Engineers, 2011. 1-11.

Roussennac B. \& Toschi, C. "Brightwater Trial in Salema Field (Campos Basin, Brazil)." SPE Paper 131299 presented at the 2010 SPE EUROPEC/EAGE Annual Conference and Exhibition. Barcelona, Spain, 14-17 June: Society of Petroleum Enginners, 2010. 1-13.

Satter A., Iqbal, G. \& Buchwalter, J. Practical Enhanced Reservoir Engineering. Tulsa, Oklahoma: PennWell , 2008. 
Seright R. S. "Discussion of SPE 89175, Advances in Polymer Flooding and Alkaline/Surfactant/Polymer Processes as Developed and Applied in the People's Republic of China." J Pet Technol 58 (2):80, 2006: 84-89.

Seright R. S., Zhang G., Akanni O. O. \& Wang D. "A Comparison of Polymer Flooding With In-Depth Profile Modification." SPE Paper 146087 presented at the 2011 Canadian Unconventional Resources Conference. Calgary, Alberta, Canada, 15-17 November: Society of Petroleum Engineers, 2011. 1-13.

Seright R. S., Prodanovic M. \& \& Lindquist B. "X-Ray Computed Microtomography Studies of Fluid Partitioning in Drainage and Imbibition Before and After Gel Placement." SPE J, 11(2): June 2006, 159-170.

Seright R. S., Fan T., Wavrik K., Wan H., Gaillard N. \& Favero, C. "Rheology of a New Sulfonic Associative Polymer in Porous Media." SPE Reservoir Evaluation $\mathcal{E}$ Engineering, 14 (6), December 2011: 726-134.

Shah A., Wood J., Greaves M., Rigby, S. \& Fishwick R. "In-situ up-grading of heavy oil/natural bitumen: Capri Process Optimisation." 8th World Congress of Chemical Engineering: Incorporating the 59th Canadian Chemical Engineering Conference and the 24th Interamerican Congress of Chemical Engineering. Montreal: Elsevier B. V., 2009. 520 e.

Shah A., Fishwick R., Wood J., Leeke G., Rigby S. \&. Greaves M. "A review of novel techniques for heavy oil and bitumen extraction and upgrading." Energy $\mathcal{E}$ Environmental Science, 3, 2010: 700-714.

Sharma M., Bryant S. \& Huh C. $p H$ Sensitive Polymers for Improving Reservoir Sweep and Conformance Control in Chemical Flooding. DOE Final Report, Austin, Texas: The University of Texas at Austin, 2008.

Shaw J. \& Bachu, S. "Screening, Evaluation, and Ranking of Oil Reservoirs Suitable for $\mathrm{CO}_{2}-$ Flood EOR and Carbon Dioxide Sequestration." JCPT, 41 (9), 2002, 51-61.

Sheng J. Modern Chemical Enhanced Oil Recovery. Theory and Practice. Burlington, MA, USA: Gulf Professional Publishing, 2011.

Shi J., Varavei A., Huh C., Delshad M., Sepehrnoori K. \& Li, X. "Viscosity Model of Preformed Microgels for Conformance and Mobility Control." Energy Fuels, 2011: 25, 5033-5037.

Shi J., Varavei A., Huh C., Sepehrnoori, K., Delshad M. \& Li X. "Transport Model Implementation and Simulation of Microgel Processes for Conformance and Mobility Control Purposes." Energy Fuels, 2011: 25, 5063-5075.

Singhal A. Preliminary Review of IETP Projects Using Polymers. Engineering Report, Calgary, Alberta, Canada: Premier Reservoir Engineering Services LTD, 2011.

Smith J. E., Liu H. \& Guo, Z. D. "Laboratory Studies of In-Depth Colloidal Dispersion Gel Technology for Daqing Oil Field." SPE Paper 62610 presented at the 2000 SPE/AAPG Western Regional Meeting. Long Beach, California, 19-23 June: Society of Petroleum Engineers Inc., 2000. 1-13.

Smith J. E., Mack J. C. \& Nicol, A. B. "The Adon Road-An In-Depth Gel Case History." SPE/DOE Paper 35352 presented at the 1996 SPE/DOE Tenth Symposium on Improved Oil Recovery. Tulsa, Oklahoma, 21-24 April: Society of Petroleum Engineers, 1996. 111. 
Soudmand-asli A., Ayatollahi S. , Mohabatkar H., Zareie. M. \& Shariatpanahi F. "The in situ microbial enhanced oil recovery in fractured porous media." Journal of Petroelum Science and Engineering, 58, 2007. 161-172.

Spildo K., Skauge A., Aarra, M. G. \& Tweheyo M. T. "A New Polymer Application for North Sea Reservoirs." SPE Paper 113460 presented at the 2008 SPE/DOE Improved Oil Recovery Symposium. Tulsa, Oklahoma, U.S.A. 19-23 April: Society of Petroleum Engineers, 2008. 1 - 9.

Sydansk R. D. \& Romero-Zerón, L. Reservoir Conformance Improvement. Richardson, Texas: Society of Petroleum Engineers, 2011.

Sydansk R. D. \& Seright, R. S. "When and Where Relative Permeability Modification WaterShutoff Treatments Can Be Successfully Applied." SPE Prod E Oper, 22(2), May 2007: 236-247.

Sydansk R. D. "Polymers, Gels, Foams, and Resins." In Petroleum Engineering Handbook Vol. V (B), Chap. 13, by Lake L. W. (Ed.), 1149-1260. Richardson, Texas: Society of Petrleum Engineers, 2007.

Taber J. J., Martin F. D. \& Seright, R. S. "EOR Screening Criteria Revisited-Part 1: Introduction to Screening Criteria and Enhanced Recovery Field Projects." SPE Resevoir Engineering, 12 (3) August 1997: 189-198.

Taber J. J., Martin F. D. \& Seright, R. S. "EOR Screening Criteria Revisited-Part 2: Applications and Impact of Oil Prices." SPE Reservoir Engineering, 12 (3) August 1997: 199-205.

Van Dyke K. Fundamentals of Petroleum (Fourth Edition). Austin, Texas: The University of Texas at Austin, 1997.

Wang D., Liu C., Wu W. \& Wang G. "Novel Surfactants that Attain Ultra-Low Interfacial Tension between Oil and High Salinity Formation Water without adding Alkali, Salts, Co-surfactants, Alcohol, and Solvents." SPE Paper 127452 at the SPE EOR Conference at Oil \& Gas West Asia. Muscat, Oman, 11-13 April: Society of Petroleum Engineers, 2010. 1-11.

Wang, D., Han P., Shao Z., Hou W. \& Seright, R. S. "Sweep-Improvement Options for the Daqing Oil Field." SPE Reservoir Evaluation E Engineering, 11 (1) February 2008: 18 26.

Wang L., Zhang G. C., Ge J.J., Li G. H., Zhang J. Q. \& Ding B. D. "Preparation of Microgel Nanospheres and Their Application in EOR." SPE Paper 130357 presented at the 2010 CPS/SPE International Oil $\mathcal{E}$ Gas Conference and Exhibition. Beijing, China, 8-10 June: Society of Petroleum Engineers, 2010. 1 - 7.

Wu Y., Shuler P. J., Blanco M., Tang Y \& Goddard III W. A. "A Study of Wetting Behavior and Surfactant EOR in Carbonates With Model Compounds." SPE Paper 99612 presented at the 2006 SPE/DOE Symposium on Improved Oil Recovery. Tulsa, Oklahoma, U.S.A.: Society of Petroleum Engineers, 2006. 1-11.

Wu, Y., Shuler P., Blanco M., Tang Y. \& Goddard, W. A. "A Study of Branched Alcohol Propoxylate Sulfate Surfactants for Improved Oil Recovery." SPE Paper 95404 presented at the 2005 SPE Annual Technical Conference and Exhibition. Dallas, Texas, U.S.A., 9-12 October: Society of Petroleum Engineers Inc., 2005. 1-10.

Yang H., Britton C., Liyanage P.J., Solairaj S., Kim D.H., Nguyen Q., Weerasooriya U. \& Pope G. "Low-cost, High -Performance Chemicals for Enhanced Oil Recovery." SPE 
paper 129978 presented at the 2010 SPE Improved Oil Recovery Symposium. Tulsa, Oklahoma, U.S.A., 24-28 April: Society of Petroleum Engineers, 2010. 1-24.

Zaitoun A., Makakou P., Blin N., Al-Maamari R.S., Al-Hashmi A. R. \& Abdel-Goad M. "Shear Stability of EOR Polymers." SPE Paper 141113 presented at the 2011 SPE International Symposium on Oilfield Chemistry. The Woodlands, Texas, U.S.A., 11-13 April: Society of Petroleum Engineers, 2011. 1-7. 


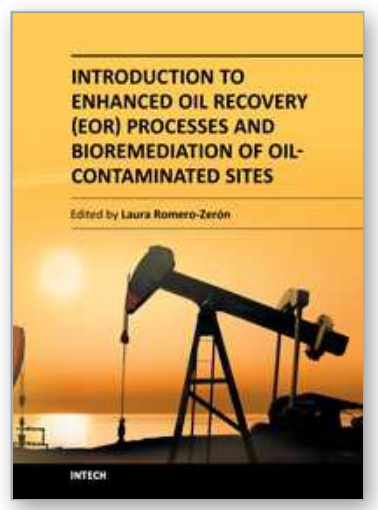

\author{
Introduction to Enhanced Oil Recovery (EOR) Processes and \\ Bioremediation of Oil-Contaminated Sites \\ Edited by Dr. Laura Romero-Zerón
}

ISBN 978-953-51-0629-6

Hard cover, 318 pages

Publisher InTech

Published online 23, May, 2012

Published in print edition May, 2012

This book offers practical concepts of EOR processes and summarizes the fundamentals of bioremediation of oil-contaminated sites. The first section presents a simplified description of EOR processes to boost the recovery of oil or to displace and produce the significant amounts of oil left behind in the reservoir during or after the course of any primary and secondary recovery process; it highlights the emerging EOR technological trends and the areas that need research and development; while the second section focuses on the use of biotechnology to remediate the inevitable environmental footprint of crude oil production; such is the case of accidental oil spills in marine, river, and land environments. The readers will gain useful and practical insights in these fields.

\title{
How to reference
}

In order to correctly reference this scholarly work, feel free to copy and paste the following:

Laura Romero-Zerón (2012). Advances in Enhanced Oil Recovery Processes, Introduction to Enhanced Oil Recovery (EOR) Processes and Bioremediation of Oil-Contaminated Sites, Dr. Laura Romero-Zerón (Ed.), ISBN: 978-953-51-0629-6, InTech, Available from: http://www.intechopen.com/books/introduction-toenhanced-oil-recovery-eor-processes-and-bioremediation-of-oil-contaminated-sites/advances-in-enhanced-oilrecovery

\section{INTECH}

open science | open minds

\author{
InTech Europe \\ University Campus STeP Ri \\ Slavka Krautzeka 83/A \\ 51000 Rijeka, Croatia \\ Phone: +385 (51) 770447 \\ Fax: +385 (51) 686166 \\ www.intechopen.com
}

\author{
InTech China \\ Unit 405, Office Block, Hotel Equatorial Shanghai \\ No.65, Yan An Road (West), Shanghai, 200040, China \\ 中国上海市延安西路65号上海国际贵都大饭店办公楼405单元 \\ Phone: +86-21-62489820 \\ Fax: +86-21-62489821
}


(C) 2012 The Author(s). Licensee IntechOpen. This is an open access article distributed under the terms of the Creative Commons Attribution 3.0 License, which permits unrestricted use, distribution, and reproduction in any medium, provided the original work is properly cited. 